NBER WORKING PAPER SERIES

\title{
GLOBALIZATION AND EXECUTIVE COMPENSATION
}

\author{
Wolfgang Keller \\ William W. Olney \\ Working Paper 23384 \\ http://www.nber.org/papers/w23384 \\ NATIONAL BUREAU OF ECONOMIC RESEARCH \\ 1050 Massachusetts Avenue \\ Cambridge, MA 02138 \\ May 2017, Revised June 2018
}

We are grateful to David Atkin, Andrew Bernard, Nick Bloom, Matilde Bombardini, Brian Cadena, Gordon Hanson, Keith Head, Peter Kuhn, Rod Ludema, Terra McKinnish, Ferdinando Monte, Nina Pavcnik, Steve Redding, Jan Schymik, Daniel Tannenbaum, Karen Helene UlltveitMoe, and numerous other colleagues, as well as participants at a variety of presentations for helpful comments and suggestions. This research was supported by NSF grant 1360207 (Keller). The views expressed herein are those of the authors and do not necessarily reflect the views of the National Bureau of Economic Research.

NBER working papers are circulated for discussion and comment purposes. They have not been peer-reviewed or been subject to the review by the NBER Board of Directors that accompanies official NBER publications.

(C) 2017 by Wolfgang Keller and William W. Olney. All rights reserved. Short sections of text, not to exceed two paragraphs, may be quoted without explicit permission provided that full credit, including $\left({ }^{\circ}\right.$ notice, is given to the source. 
Globalization and Executive Compensation

Wolfgang Keller and William W. Olney

NBER Working Paper No. 23384

May 2017, Revised June 2018

JEL No. F14,J3

\begin{abstract}
$\underline{\text { ABSTRACT }}$
This paper finds that globalization is contributing to the rapid increase in executive compensation over the last few decades. Employing comprehensive data on top executives at major U.S. companies, we show that their compensation is increasing with exports and foreign direct investment, as well as firm size and technology. Exogenous export shocks unrelated to managerial decisions also increase executive compensation, and there is little evidence that this is due to increasing market returns to talent. We do find that export shocks primarily affect discretionary forms of compensation of more powerful executives at firms with poor corporate governance, as one would expect if globalization has enhanced rent-capture opportunities. Overall, these results indicate that globalization has played a more central role in the rapid growth of executive compensation and U.S. inequality than previously thought.
\end{abstract}

\author{
Wolfgang Keller \\ Department of Economics \\ University of Colorado, Boulder \\ Boulder, CO 80309-0256 \\ and NBER \\ Wolfgang.Keller@colorado.edu \\ William W. Olney \\ Department of Economics \\ Williams College \\ Williamstown, MA 01267 \\ william.olney@williams.edu
}




\section{Introduction}

"American policy has allowed the winners to keep most of the spoils of trade and has given the losers crumbs. This has exacerbated income inequality by raising the profits of big corporations and the salaries of executives and other white collar professionals while leaving blue-collar and lower-skilled workers poorer" New York Times Editorial April 2, 2016

Globalization and income inequality are currently two of the most important economic issues, with dissatisfaction about both shaping elections throughout the world. While there is a common perception that these issues are related (as illustrated by the quote above), research has tended to focus on the impact of globalization on blue-collar workers. However, it is high incomes, especially the top 1\%, that appear to drive U.S. inequality, as Figure 1 shows: $^{1}$

FIGURE 1

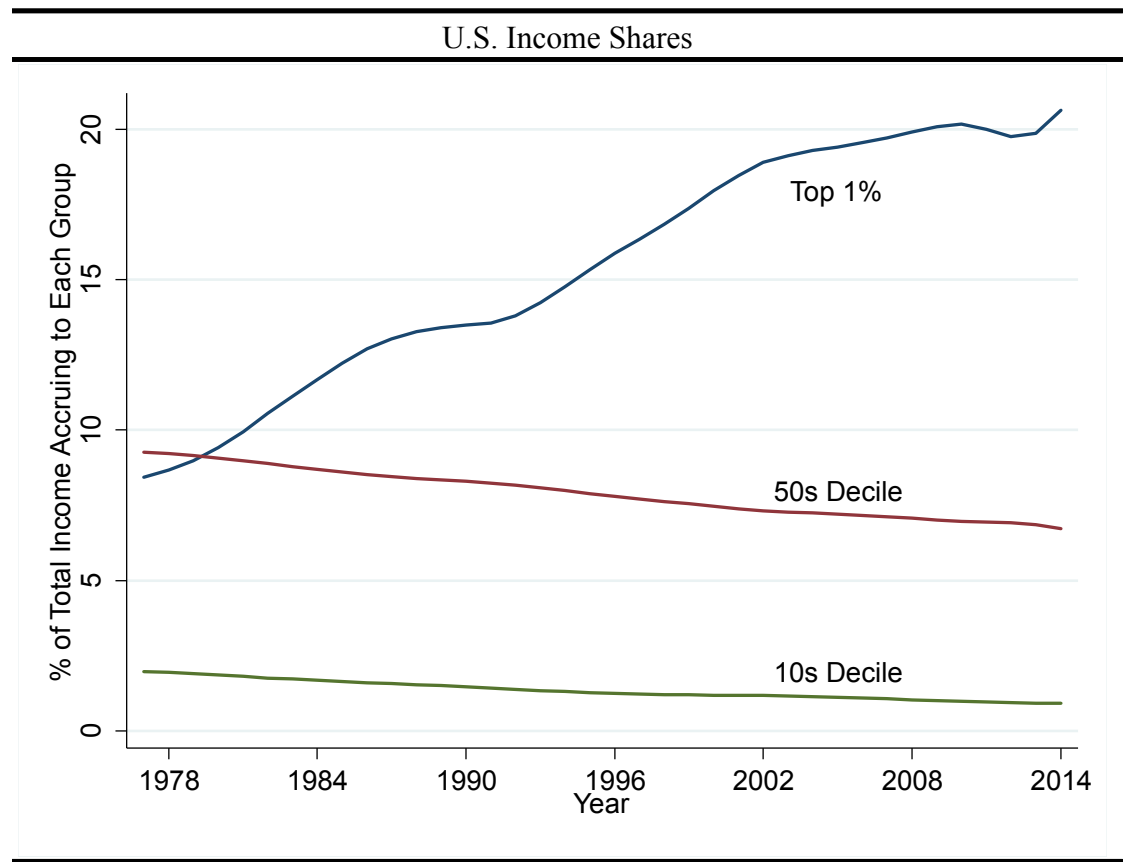

Notes: Kernel-weighted local polynomial smoothed data from World Wealth and Income Database (WID; website: wid.world).

This paper examines the relationship between globalization and growing inequality by focusing on the incomes of top business executives. By 2013, the typical top business executive of a Standard and Poor 500 Indexed firm earned $\$ 3.7$ million a year, while Chief Executive Officers (CEOs) made $\$ 7.5$ million a year,

\footnotetext{
${ }^{1}$ We also show the evolution of all U.S. income deciles in Appendix A.1.
} 
putting both safely within the top $1 \%$ of all income earners. ${ }^{2}$ Moreover, non-finance business executives are by far the largest share of the top $1 \%$ and are representative of the top $1 \%$ more generally (Bakija, Cole, and Heim 2012, Kaplan and Rauh 2013). Furthermore, executive compensation is rising relatively quickly, with CEO pay increasing more than eight times as fast as average worker pay over the last three and half decades (Edmans, Gabaix, and Jenter 2017). We study business executives, but compensation in other fields like entertainment and sports may be even more susceptible to globalization. ${ }^{3}$

While the income trends of Figure 1 are well-documented and exist in most high-income countries, the causes of this growth in inequality have remained controversial. ${ }^{4} \mathrm{~A}$ variety of explanations have been proposed, but globalization has rarely been a focus (e.g. Bertrand 2009). Thus, our first goal is to examine whether globalization is contributing to the rapid increase in top incomes. Figure 2 shows that over the last seventy years there has been a rapid increase in both executive compensation and exports (we will also analyze foreign direct investment and imports). While gross domestic product (GDP) is also trending upwards, executive compensation is more closely associated with exports. This does not imply causality, but it does suggest that the question of whether globalization has contributed to rising executive compensation is potentially important.

\footnotetext{
${ }^{2}$ The threshold depends to some extent on whether measures of total income or labor income are employed; Guvenen and Kaplan (2017) discuss a number of major issues. Piketty, Saez, and Zucman (2017) note that $\$ 1.3$ million is the average pre-tax income of the top $1 \%$ in 2014, with the cutoff lower than that. Guvenen, Kaplan, and Song (2014) show that the $1 \%$ wage and salary threshold in 2012 was $\$ 291,000$ based on a 10\% sample of Social Security Administration data, with wages and salaries accounting for about $60 \%$ of total income for the top $1 \%$ individuals.

${ }^{3}$ Entertainment and sports superstars have benefited from the ability to reach large global audiences (e.g. Gordon and Dew-Becker 2008).

${ }^{4}$ Appendix A.2 shows that the share of income going to the top $1 \%$ is increasing in most OECD countries. Gordon and Dew-Becker (2008) and Edmans, Gabaix, and Jenter (2017) examine why the trend is quantitatively stronger in the US.
} 


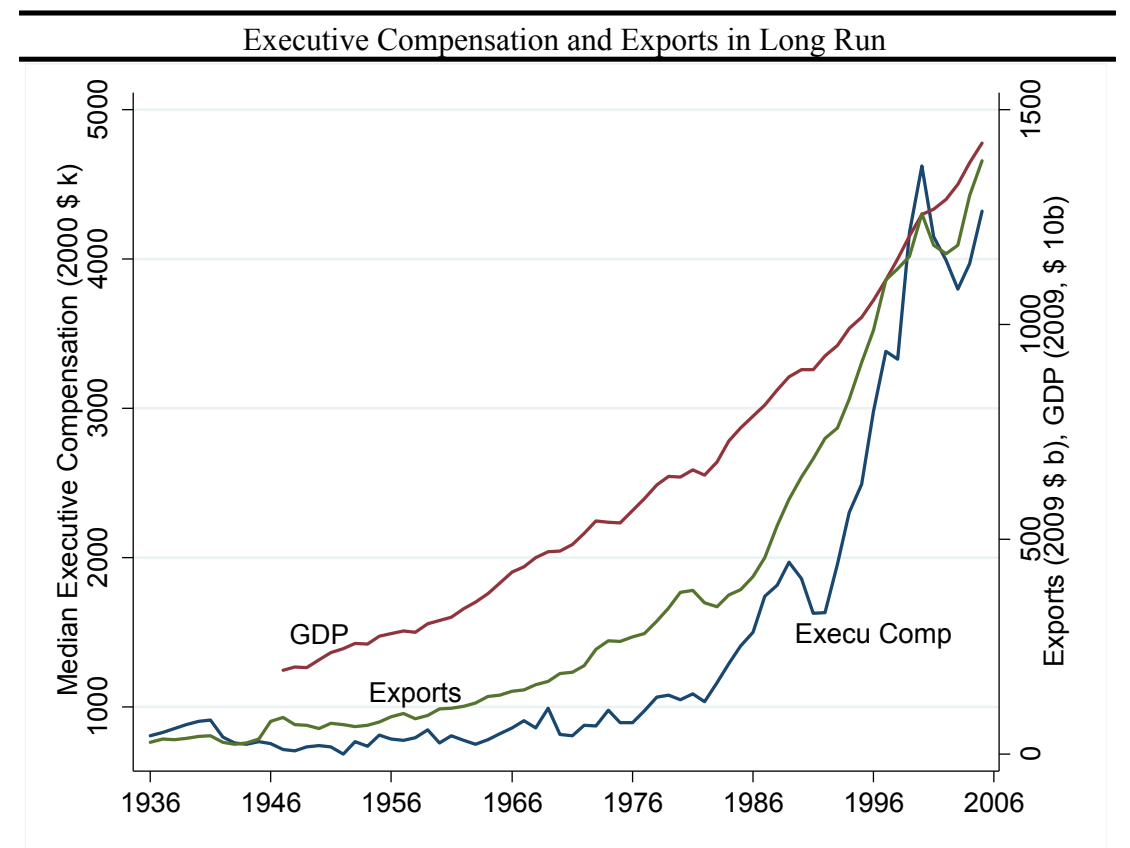

Notes: Data on the median compensation of the three highest paid executives at the 50 largest U.S. firms comes from Frydman and Saks (2010). Total compensation includes salary, bonuses, stocks, and options granted (valued using Black Scholes). Real U.S. GDP and export data comes from FRED (St. Louis Fed)

To the extent that globalization matters for executive compensation, our second goal is to understand why it increases executive pay. First, perhaps market forces reward talented executives who make strategic decisions that expand their firm abroad. Such executives earn more because they successfully navigate the logistics of selling to many markets, deal with the complexity of setting up production stages that span numerous countries, and overcome bargaining and contractual issues in foreign countries. In this case, globalization's effect on pay is the result of the executive's talent and actions. Pay increases can also be due to market forces outside the executive's control that increase the importance of top talent. For instance, globalization can increase optimal firm size (Melitz 2003), and it may induce the reassignment of the most talented managers to the strongest firms (Gabaix and Landier 2008, Terviö 2008). Globalization may also increase pay because it generates new competition for managerial talent (Marin and Verdier 2012) or because it changes the firm's organizational structure (Rajan and Wulf 2006, Caliendo, Monte, and Rossi-Hansberg 2015). In short, globalization may alter the nature of the executive's job, increase the importance of top talent, and thus lead to higher pay (see Rosen 1981). ${ }^{5}$ We will refer to these components of increasing executive pay as market returns.

\footnotetext{
${ }^{5}$ In addition, there is evidence that executives now have better outside options because they are increasingly externally recruited and have general, not firm-specific, skills (Murphy and Zabojnik 2006, Frydman 2016).
} 
Second, globalization can increase executive pay through non-market channels. In particular, rentcapture is an important determinant of executive pay (Bertrand and Mullainathan 2001, Bebchuk and Fried 2004, Bivens and Mishel 2013) and we investigate if globalization facilitates these activities. The sheer size of global firms alone might enhance rent-capture opportunities, or international transactions might make it harder for shareholders, board members, as well as regulatory and tax authorities to monitor executives. Globalization induced rent-capture activities may be more feasible for certain types of pay, executives, and firms. By intensifying competition for talent, globalization may also make very high salaries more acceptable by shifting social norms (Piketty and Saez 2003, 2006), which facilitates future rent-capture. Higher levels of competition may also encourage bench-marking executive pay to a relevant peer group, which has been found to inflate corporate pay (Bizjack, Lemmon, and Nguyen 2011). We will refer to these pay increases as non-market returns.

Distinguishing between market and non-market returns is important because it influences society's willingness to tolerate inequality. If pay reflects market forces that optimally reward the executive's talent and actions, inequality will be less objectionable than if executive pay increases due to rent-capture. In addition to the immediate distributional implications, executive compensation has been a controversial topic with broader ramifications (see Bertrand 2009, Edmans, Gabaix, and Jenter 2017). Rising executive pay, especially due to rent-capture, can lead to polarization and undermine social cohesion. ${ }^{6}$

The relationship between globalization and top incomes is studied by examining the impact of exports, imports, and foreign direct investment (FDI) on the compensation of executives over the years 1993 to 2013. Our analysis focuses on top executives at publicly traded U.S. firms from Compustat's comprehensive and well-known ExecuComp data set. We examine whether globalization is influencing top incomes, and if so whether this relationship reflects market or non-market returns.

In line with the simple correlation in Figure 2 our first finding is that firm-specific exports, identified using detailed product level trade and firm sales data, have a significant positive impact on executive compensation. An important contribution of our paper is that while firm size and technology investments raise executive compensation, exports increase pay conditional on these and other firm characteristics. ${ }^{7}$ In addition, a portion of export's impact on executive pay operates through size and technology, indicating that globalization affects pay through these market channels. Quantitatively, we find that the magnitude

\footnotetext{
${ }^{6}$ On the impact of globalization on economic polarization, see Keller and Utar (2016). On the link between globalization and political polarization, see Autor, Dorn, Hanson, and Majlesi (2016), Dippel, Gold, Heblich, and Pinto (2017), and Che, Lu, Pierce, Schott, and Tao (2017) .

${ }^{7}$ We also condition on a variety of other firm and industry characteristics, such as insider board relationships, markups, and value added. We also explore whether top marginal tax rates influence executive compensation (Piketty, Saez, and Stantcheva 2014) although the available data is more limited.
} 
of export's impact on executive compensation is comparable to that of firm size and technology. Results also show that exports increase executive pay more than average worker wages, and that compensation increases more with foreign affiliate sales than with domestic sales. Overall, these results indicate that globalization has been a more important force behind the increase in executive compensation and inequality than generally perceived.

Second, we examine why globalization is increasing executive compensation. We employ a Bartik (1991) style shift-share instrument that identifies exogenous export shocks which are by construction independent of the executive's actions. ${ }^{8}$ The results indicate that a $10 \%$ exogenous export shock leads to a $3 \%$ increase in the compensation of executives. ${ }^{9}$ Using a back-of-the-envelope calculation this estimate indicates that exports can account for about a third of the observed increase in executive compensation over this period. ${ }^{10}$ Even though export shocks are not caused by managerial decisions they can nevertheless alter market characteristics which in turn increase executive pay. For instance, a positive shock may encourage firms to match with a better, more highly paid executive, or it may drive up the returns to talent by changing the nature of the manager's job. Consistent with assortative matching, we find that export shocks lead to more executive turnover and higher pay for newly hired executives, however the magnitudes of these effects are small. Furthermore, we find no evidence that export shocks lead to higher returns to more skilled executives. ${ }^{11}$

Lacking strong evidence for a market returns explanation, we turn to the non-market explanation of rent-capture. Evidence of asymmetry, where executive compensation increases with positive shocks but does not decrease with negative shocks, suggests that it might be important. We go further by first exploiting the fact that some forms of compensation are set in a more discretionary way than others, and thus are more susceptible to rent-capture. Export shocks are found to strongly increase bonus payments, with little impact on less-discretionary forms of compensation like salary. ${ }^{12}$ Second, we exploit the fact

\footnotetext{
${ }^{8}$ Our instrument is constructed using presample industry-level bilateral export flows and exogenous industry-level export growth in other high-income countries. Examples of instrumental variables strategies based on other countries include Haskel, Pereira, and Slaughter (2007), Autor, Dorn, and Hanson (2013), and Blanchard and Olney (2017). Similar results are obtained using alternate instrument variable strategies based on world import demand and exchange rate fluctuations.

${ }^{9} \mathrm{An}$ added benefit of focusing on globalization is that it is easier to identify exogenous shocks that are unrelated to domestic conditions. We suspect that domestic shocks may also influence executive compensation but it is more challenging to identify these empirically.

${ }^{10}$ Multiplying export growth $(168 \%)$ and our point estimate $(0.300)$, implies exports increased TDC1 by $50 \%$ from 1993 to 2013. This represents about a third of the observed increase in TDC1 (141\%) over this period.

${ }^{11}$ Related to this analysis is the concept of relative performance evaluation (RPE; Holmström 1979), which implies that optimal contracts should only reward executives for relative performance differences. The lack of RPE is well documented (Gibbons and Murphy 1990 and others). Under certain conditions, e.g. when there are constraints on the feasible set of contracts, the optimal contract need not satisfy RPE (see Edmans, Gabaix, and Jenter 2017). We have examined this issue and found little evidence that our results are driven by common explanations for why RPE would not hold (results available upon request).

${ }^{12}$ In principle, the stock-option innovation of the 1990 s may have been important for diverting additional rents to top
} 
that rent-capture is more likely at poorly governed firms and indeed our results show that the impact of exogenous export shocks is stronger at those firms with insider board relationships. Finally, we take into account the fact that some executives have more managerial power to influence pay decisions than others. In particular, we show that the effect of export shocks on bonuses is strongest for CEOs of poorly governed firms. Together these results indicate that rent-capture associated with globalization has been an important factor in the rise of executive compensation.

We verify that the results are robust to (i) a wide variety of alternate specifications that account for unobserved executive, executive-by-firm, and industry-by-year conditions, (ii) employing alternate measures of firm size, (iii) addressing possible selection by using different samples, (iv) dealing with the potential endogeneity of poor governance, and (v) examining the role of imports. ${ }^{13}$ Overall, we show that globalization has contributed to the recent rise in top-incomes by increasing executive compensation.

The paper makes a number of contributions. First, it speaks to important work assessing the impact of globalization on inequality. Early studies concluded that skill-biased technical change may have been more important than globalization in explaining rising inequality (Katz and Autor 1999, Feenstra and Hanson 1999). However, this literature tended to focus on the distinction between skilled and unskilled workers, not the role of the top $1 \%$ of income earners. More recently there has been a growing consensus that rising import competition, driven in part by China (Krugman 2008), has adversely affected blue-collar workers (Autor, Dorn, and Hanson 2013, Pierce and Schott 2016). Our analysis complements this work by shifting the focus to exports, foreign direct investment, and the gains experienced by high-income earners. ${ }^{14}$ This is important because high-income earners, especially the top 1\%, are arguably the most important drivers of income inequality (see Figure 1, as well as Piketty and Saez 2003, 2006, Piketty, Saez, and Zucman 2017).

Second, while anecdotal evidence indicates that globalization is contributing to rising executive compensation, to date it has received little attention from researchers. Globalization is sometimes dismissed as a potential explanation because it should be ubiquitous whereas the trends in top income shares across countries differ (Alvaredo, Atkinson, Piketty, and Saez 2013, Piketty, Saez, and Stantcheva 2014). ${ }^{15}$ Others argue that globalization should affect occupations differently whereas the trends in top incomes across occupations are the same (Kaplan and Rauh 2013). In contrast, our analysis is based on longitudinal, executives (Bebchuk and Fried 2004, Bertrand 2009); we will explore this dimension of the data in sections 5.2 and A.6.

${ }^{13}$ Imports are found to have an insignificant impact on executive compensation (see Appendix A.7).

${ }^{14}$ Hummels, Jorgensen, Munch, and Xiang (2014) study the impact of exports on wages, although they do not focus on top incomes.

${ }^{15}$ While there is certainly variation in top income growth rates across countries, Figure A2 shows a clear upward trend across a diverse set of OECD countries (see Appendix A.2). 
micro-level data that addresses many potential sources of spurious results. Globalization is a promising long-run explanation for the changing pattern of executive pay over the last century. Any successful explanation needs to deal with why executive pay was relatively flat prior to 1980 and has increased dramatically thereafter (recall Figure 2). Insider board relationships is a prominent explanation for rising executive pay (Bertrand and Mullainathan 2001), however by most measures corporate governance has strengthened, not weakened, since 1980. ${ }^{16}$ Growth in firm size is another common explanation for the recent increase in executive compensation (Gabaix and Landier 2008). However, firm size also increased from the 1940s to the early 1970s when CEO compensation was virtually flat (Frydman and Saks 2010). In contrast, globalization provides a compelling explanation for the evolution of executive compensation because the time series variation in exports and executive compensation track each other closely before and after 1980 (see Figure 2).

Third, we provide a unifying analysis of the executives' market and non-market returns, which are too often treated as mutually exclusive explanations. Our findings show that executive compensation is increasing with market forces such as firm size and technology investments, consistent with Gabaix and Landier (2008) and Garicano and Rossi-Hansberg (2006), respectively. A portion of globalization's impact on executive pay operates through size and technology, while another portion affects pay after holding size and technology constant, a finding that is new to the literature. ${ }^{17}$ We find that executive pay increases with shocks unrelated to executive action, as in Bertrand and Mullainathan (2001), and that market returns explain only a small part of the observed relationship between export shocks and compensation. Furthermore, evidence showing that positive shocks increase executive pay but negative shocks do not decrease pay point to rent-capture. ${ }^{18}$ We confirm this by showing that export shocks disproportionately increase discretionary pay to powerful managers at poorly governed firms. Overall, our findings show that both market and non-market forces are important in explaining the rapid rise in executive compensation.

The paper proceeds as follows. In the next section, we discuss the data sources employed in this analysis, provide background information on executive compensation, and describe the main relationship between executive pay and exports. Section 3 tackles our first key question of whether globalization is

\footnotetext{
${ }^{16}$ For example, due to possible conflicts of interest the Security and Exchange Commission (SEC) started requiring firms in 2006 to disclose the role and identity of all paid compensation consultants, and in 2010 the Dodd-Frank Act strengthened this to stipulate that only independent consultants can be hired. Indeed, Chhaochharia and Grinstein (2009) find strong decreases in CEO compensation at firms affected by Sarbanes-Oxley-inspired legislation which required that the majority of a board's directors be independent. In fact, some argue that higher executive pay should be viewed as compensation for the hassle of increased regulatory requirements (Hermalin 2005). See Murphy and Zabojnik (2004) and Edmans, Gabaix, and Jenter (2017) for more discussion.

${ }^{17}$ For instance, Ma (2015) finds no relationship between exports and executive pay once firm size is accounted for.

${ }^{18}$ See also Bertrand and Mullainathan (2001) and Garvey and Milbourn (2006) on this asymmetry.
} 
contributing to the rapid increase in executive pay. Confirming this to be the case, we then proceed to our second question: why is this occurring? Specifically, in Section 4 we find that export shocks that are orthogonal to executive actions and other domestic conditions nonetheless increase executive compensation. Furthermore, the evidence that these export shocks increase market returns through assortative matching or through increasing returns to talent is weak. We turn our attention to rent-capture in Section 5, finding that export shocks increase discretionary pay to powerful managers at poor governance firms. We explore a variety of extensions in both Section 6 and in the Appendix, which shed additional light on the relationship between globalization and executive pay as well as demonstrates that the results are robust to alternate specifications and samples.

\section{Data}

The empirical analysis utilizes executive compensation data, firm and executive level information, and globalization data from the following sources.

\subsection{Executive Compensation}

Compensation information of the top five executives within each Standard \& Poor (S\&P) firm was obtained from the Compustat ExecuComp data set. This is the most comprehensive publicly available data set on executive compensation, with information about each executive, including their name and identifier as well as their company's name and identifier. Importantly, the data set has detailed administrative compensation information based on company filings with the U.S. Securities and Exchange Commission (SEC).

Our measure of executive compensation is ExecuComp's TDC1, which includes total compensation awarded to an executive in a given year. An alternative measure, TDC2, captures compensation realized by an executive in a given year. Globalization may have a different impact on compensation realized and compensation awarded, given that the executive has more influence over the former than the latter. By employing the TDC1 measure we eliminate the possibility that executives strategically exercise their stock options in response to positive shocks. ${ }^{19}$

An appealing feature of this executive compensation data is that it also provides detailed information on individual components of compensation, allowing us to examine how globalization affects more and less discretionary types of pay. The five components of executive pay are salary, bonuses, stock options awarded, stock awards, and other compensation. Salary is the executive's base salary while bonuses includes

\footnotetext{
${ }^{19}$ The results in Table A8 confirm this by showing that export shocks have a larger impact on TDC2 than TDC1.
} 
bonuses and long-term non-equity incentive plans. Options give the value of stock options awarded, stocks are the value of restricted stock granted, and other compensation includes personal benefits, 401k plans, life insurance premiums, termination payments, and tax reimbursements, among other components. Note that all nominal compensation values are converted to constant 2014 U.S. dollars using the Consumer Price Index (CPI) provided by the Bureau of Labor Statistics.

On average in 2013, a top five executive in our sample earned $\$ 3.7$ million which consisted of about $\$ 0.6 \mathrm{~m}$ of salary, $\$ 0.8 \mathrm{~m}$ of bonuses, $\$ 0.6 \mathrm{~m}$ of options, $\$ 1.4 \mathrm{~m}$ of stocks, and $\$ 0.2 \mathrm{~m}$ of other compensation (in 2014 dollars). By comparison, CEOs earned $\$ 7.5 \mathrm{~m}$ overall which consisted of $\$ 1.0 \mathrm{~m}$ of salary, $\$ 1.7 \mathrm{~m}$ of bonuses, $\$ 1.5 \mathrm{~m}$ of options, $\$ 3.0 \mathrm{~m}$ of stocks, and $\$ 0.4 \mathrm{~m}$ of other compensation. Our subsequent analysis will exploit the fact that export shocks may affect these components of executive pay differentially.

The relative importance of these forms of compensation over time is presented on the left hand side of Figure $3 .^{20}$ Consistent with other findings, this figure shows that options represented a larger share of compensation in the late 1990s, while stocks represent a larger share of pay more recently (see Frydman and Jenter 2010, and Edmans, Gabaix, and Jenter 2017 for additional details). The growth in the importance of stock options since the 1970s is often emphasized, however cash remunerations such as salary and bonuses have been factors as well (Bertrand 2009).

FIGURE 3

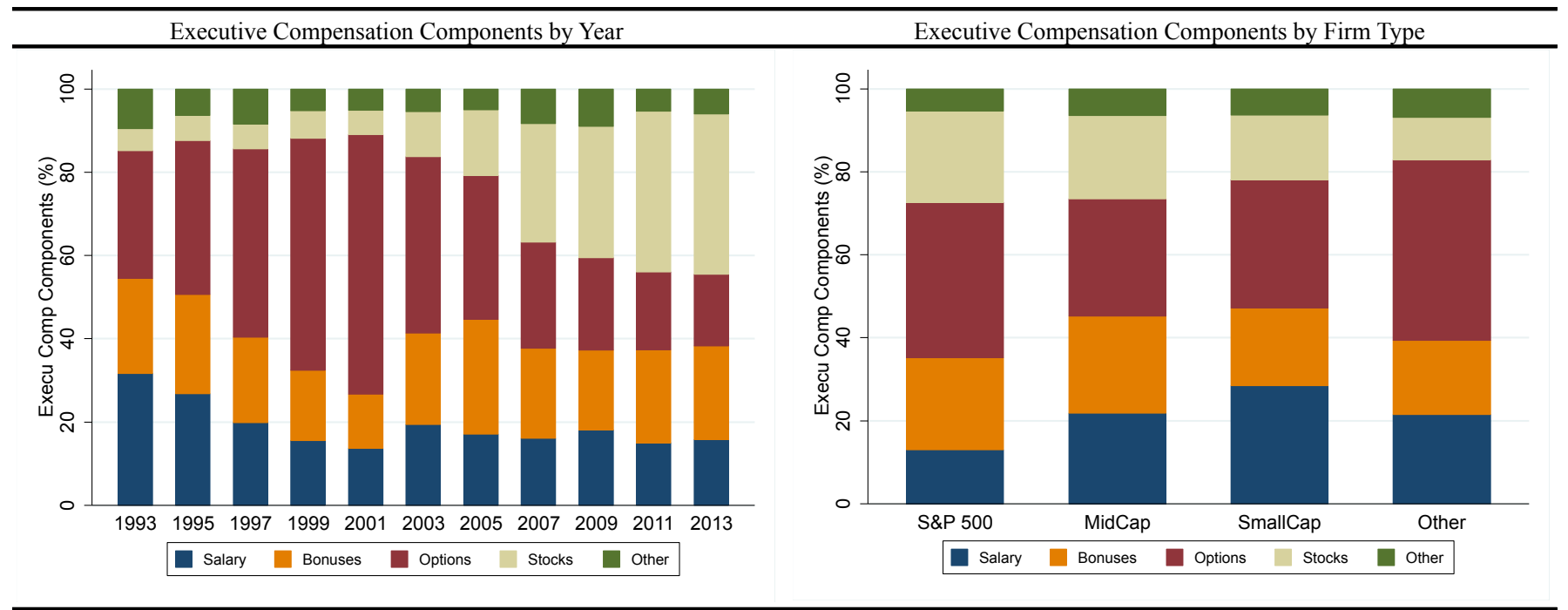

Notes: Salary includes the executive's base salary, Bonuses includes bonuses and long-term non-equity incentive plans, Options are the value of stock options awarded, Stocks are the value of restricted stock granted, and Other is all other compensation received by the executive. Source: ExecuComp

The right hand side of Figure 3 examines the composition of pay across different firm types. Following common distinctions in the literature, we focus on S\&P 500 firms, S\&P MidCap firms, S\&P SmallCap firms,

\footnotetext{
${ }^{20}$ The SEC changed its reporting rules in 2006 and our analysis takes into account these definitional changes.
} 
and Other firms. We find that salary, for instance, represents a somewhat lower share of compensation at S\&P 500 firms (13\%) and a higher share at SmallCap firms (28\%) on average in our sample. In contrast, bonuses are fairly consistent across firm type at around $20 \%$ of total compensation. While there are some differences, overall the composition of compensation is similar across firm type, which is line with other evidence (see Edmans, Gabaix, and Jenter 2017). Appendix A.5 shows that our results are similar across different samples of firms.

\subsection{Globalization}

Our main measure of globalization is international trade, given its excellent coverage and the fact that it is often correlated with other forms of globalization. Detailed U.S. export and import data at the Harmonized System (HS) ten-digit product level for the years 1989-2012 come from the U.S. Census Bureau via Schott's International Economics Resource Page (Schott 2008), since Compustat does not report firm exports. These nominal trade flows are converted to constant 2014 U.S. dollars using the consumer price index (CPI). An appealing aspect of this data set is that the HS ten-digit trade flows are linked to the six-digit industry codes of the North American Industry Classification System (NAICS). This enables us to merge this trade data with the ExecuComp data which reports the six-digit NAICS industries of the executive's firm. Furthermore, this data set reports detailed product level trade at the bilateral level (U.S. flows to any particular foreign country), which is used in our instrumental variable analysis. While our primary interest lies in how access to foreign markets via exports affect executive compensation, we also cover the role of imports and foreign direct investment in our analysis.

A firm-specific measure of exports is constructed as the weighted average of detailed product-level exports, where the weights are the share of sales of the firm's three largest business segments. ${ }^{21}$ Accounting for the fact that many firms in our data set operate in several industries improves our ability to measure exports and its impact on executive pay. ${ }^{22}$ Since the industry in which the firm operates may evolve endogenously over time, we focus on the firm's composition of sales in the presample years of 1990-1992. This approach exploits the evolution of product-level exports over time which affects some firms more

\footnotetext{
${ }^{21}$ This utilizes Compustat's Business Segment data and focuses on business segments for which export data is available. Findings are not sensitive to the number of business segments included in the analysis - results are similar using only the firm's top business segment (Table A8) or the top five business segments (unreported).

${ }^{22}$ Firm-level export data would be more precise, however identifying a causal relationship between firm-level exports and executive compensation is challenging given unobserved firm shocks. Furthermore, in practice executive pay is often benchmarked against compensation at a relevant peer group of firms, which implies that industry-level global expansion is especially important for executive compensation. Our firm-specific export measure strikes a balance between these considerations. Also, we provide evidence on the relationship between executive compensation and a firm-level measures of globalization in our FDI analysis (section 6.2).
} 
than others based on their presample share of sales. Thus, we follow a long literature that uses industry level trade exposure which disproportionately affects some plants, firms, and regions based on their initial industry composition (e.g. Trefler 2004, Cuñat and Guadalupe 2009, Autor, Dorn, and Hanson 2013).

Our analysis also employs an alternate measures of globalization, namely foreign direct investment of U.S multinationals, measured using firm-level foreign affiliate sales data reported by Compustat. Results show that foreign sales also increase executive pay which indicates that globalization broadly defined (i.e. not just exports) is increasing compensation. Although there are data constraints, in terms of the years covered, we find these additional results compelling and a valuable complement to our export findings.

\subsection{Firm, Industry, \& Executive Information}

The ExecuComp data set is linked to the companion Compustat data set using a unique firm identifier which allows us to merge executive compensation information with other firm-level measures in the larger Compustat data set. In this way we can analyze the role of several factors that have been found to affect executive pay.

Following the insights of Gabaix and Landier (2008) and others, we include firm size as a predictor of executive compensation. Our main measure of size is the firm's number of workers. We prefer to utilize employment rather than firm sales because the former is a stronger predictor of executive compensation (see Table A4) and because sales mechanically includes exports. ${ }^{23}$ However, we show that our findings are similar if we proxy for size using firm employment, sales, assets, costs, stock price, or market value (see Table A4).

Technological change, in particular in the form of information and communication technology, is likely to affect executive compensation (see Antràs and Rossi-Hansberg 2009, Garicano and Rossi-Hansberg 2006). We measure technology investment using information on the capital expenditures of the firm, as in Feenstra and Hanson (1999), and alternatively by R\&D expenditures. As shown in Table A8 far fewer firms report information on $R \& D$, yet the estimated impact of exports on executive compensation remains largely unchanged.

By encouraging skimming or rent-capture, poor corporate governance may be an important driver of executive compensation (e.g., Bertrand and Mullainathan 2001). Building on existing approaches, we measure governance using information on the relationship between the executives and the board of directors

\footnotetext{
${ }^{23}$ Furthermore, we prefer employment to market value because both market value and executive compensation are typically a function of the firm's stock price, and thus a positive correlation is not surprising (e.g., Himmelberg and Hubbard 2000).
} 
of the company, whose tasks include making compensation decisions. ${ }^{24}$ Specifically, our interlock measure is defined as a binary variable indicating whether any executive at the firm (in a given year) serves on the board's compensation committee, or serves on another company's compensation board that has an executive serving on their board. Firms that have executives determining their own compensation may be more prone to rent-capture. Alternatively, we utilize a different measure of board composition, board, that is defined as a binary variable indicating whether three or more executives serve on the board of directors. This measure does not focus on the compensation committee per se, but rather captures the more general influence of executives on the board of directors. ${ }^{25}$

We recognize that the corporate governance of the firm may itself be endogenous. To assess the importance of this we define alternate measures of insider board relationships which eliminate all short-run potentially endogenous fluctuations in corporate governance. Employing these measures leads to similar results (Table A6). Also note that the incidence of insider board relationships has declined towards the end of the sample period due in part to the 2002 Sarbanes-Oxley Act and other legislation designed to improve corporate governance.

Executive compensation may also respond to firm markups, which have been steadily increasing since 1980 (De Loecker and Eeckhout 2017). Firms with higher markups are likely to be more profitable and thus may be able to pay their executives more. We measure markups using information on total sales and the total cost of goods sold, both from Compustat. ${ }^{26}$

In addition to these firm characteristics, we also account for broader industry-level conditions that could potentially influence the relationship between executive compensation and globalization. Specifically, we include a measure of industry value added provided by the Bureau of Economic Analysis at approximately the 3-digit NAICS level. In Appendix A.5 we also examine the impact of top marginal tax rates in the firm's headquarter state on executive compensation (see Piketty, Saez, and Stantcheva 2014).

Finally, we include a number of executive characteristics in the analysis. While the availability of executive-level variables is less comprehensive than firm-level data, we have information on experience, education, and gender. Experience is defined as the number of years the individual has been a top five

\footnotetext{
${ }^{24}$ There is scope for conflicts of interest because, for example, directors receive compensation for serving on the company's board. Bebchuk and Fried (2004) report that directors at the largest firms receive on average $\$ 152,000$ annually.

${ }^{25}$ We have also considered several corporate governance indices, including the "Governance Index" constructed by Gompers, Ishii, and Metrick (2003) and the "Entrenchment Index" constructed by Bebchuk, Cohen, and Ferell (2008). However the coverage of both of these variables is limited: they are only available every few years between 1990 and 2006 . We lose three quarters of our sample when these governance proxies are included and thus strong inferences are not possible. Findings in Appendix A.8 use an alternate measure of poor governance, defined using the co-movement of executive pay and the firm's stock price, and show the results are similar.

${ }^{26}$ Firm-specific markups are calculated as $0.85^{*}$ (total sales / total costs of goods sold) following De Loecker and Eeckhout (2017) page 37.
} 
executive at any firm in the ExecuComp data set. ${ }^{27}$ Education is defined as whether the executive has a doctorate degree. Another appealing feature of the data is that we can observe individuals entering and exiting the top echelon of a firm. Executive turnover may be important for executive pay given the predictions of competitive assignment models discussed in section 4.3.

\subsection{Descriptive Statistics}

Table 1 reports summary statistics of our key variables. For obvious reasons our analysis is restricted to industries for which there is information on trade and foreign direct investment. ${ }^{28}$ Furthermore, the handful of firms that report compensation information for fewer than five executives are dropped from the analysis. For firms that report compensation information for more than five executives, only the top five are included in the sample. This ensures that each firm in the sample has compensation information for exactly their five highest paid executives. ${ }^{29}$

Our sample includes approximately 48,000 observations and covers close to 11,000 executives, about 800 firms, 204 six-digit NAICS industries, and two decades (years 1993-2013). As we see in Table 1, the mean natural log of executive compensation across all years is 7.38 , which translates into pay of approximately $\$ 1.6 \mathrm{~m}$ per year (in 2014 dollars). For CEO's, executive compensation averages $\$ 3.4 \mathrm{~m}$ across all years (not reported). Both findings are consistent with the 2013 compensation values discussed in section 2.1. We also see that $6 \%$ of the sample has interlock relationships and $16 \%$ of the sample has three or more executives on the board (board). Executives have on average five years of experience as a top five manager, the large majority of executives in our sample are male, and a small fraction have a doctoral degree.

The compensation, trade, firm-level, and executive-level variables are similar across different samples and as a consequence our results are robust to the use of alternate samples (see Table A5). Furthermore, results from Figures 3 indicate that the executive compensation components in our sample are similar in relative size to those found in the literature. We also confirm in Figure A3 that executive compensation and globalization have both increased substantially over our sample period, with trends similar to those seen in Figure 2, which provides additional external validity for our analysis.

To gain further insight into the data, the left panel of Figure 4 plots the average executive compensation at the firm against lagged exports. A significant positive relationship emerges (the dotted lines give the

\footnotetext{
${ }^{27}$ The results are similar if experience is defined as the number of years that the executive has been at the firm or the number of years the executive has been the CEO of the firm (see section 4.4).

${ }^{28}$ For instance, services industries are excluded. Note that globalization may have an even stronger impact on service industries such as finance and entertainment, than on the mostly manufacturing industries that are included in our analysis.

${ }^{29}$ Section 5.4 examines whether globalization differentially affects executives within this group of top executives.
} 
95\% confidence interval), which is consistent with the hypothesis that firms that are more integrated into global markets pay their executives more. However, this relationship could arise, for example, because both variables are trending upwards or because unobserved firm characteristics are correlated with both exports and executive compensation. To account for these and other confounding factors, the right panel controls for both firm and year fixed effects and plots the residuals. Our baseline analysis exploits these within-firm changes over time, and a significant positive relationship is evident. ${ }^{30}$ It is encouraging that this finding emerges in such a raw cut of the data. The remainder of the paper examines several key aspects of this relationship in a more rigorous econometric analysis.

FIGURE 4

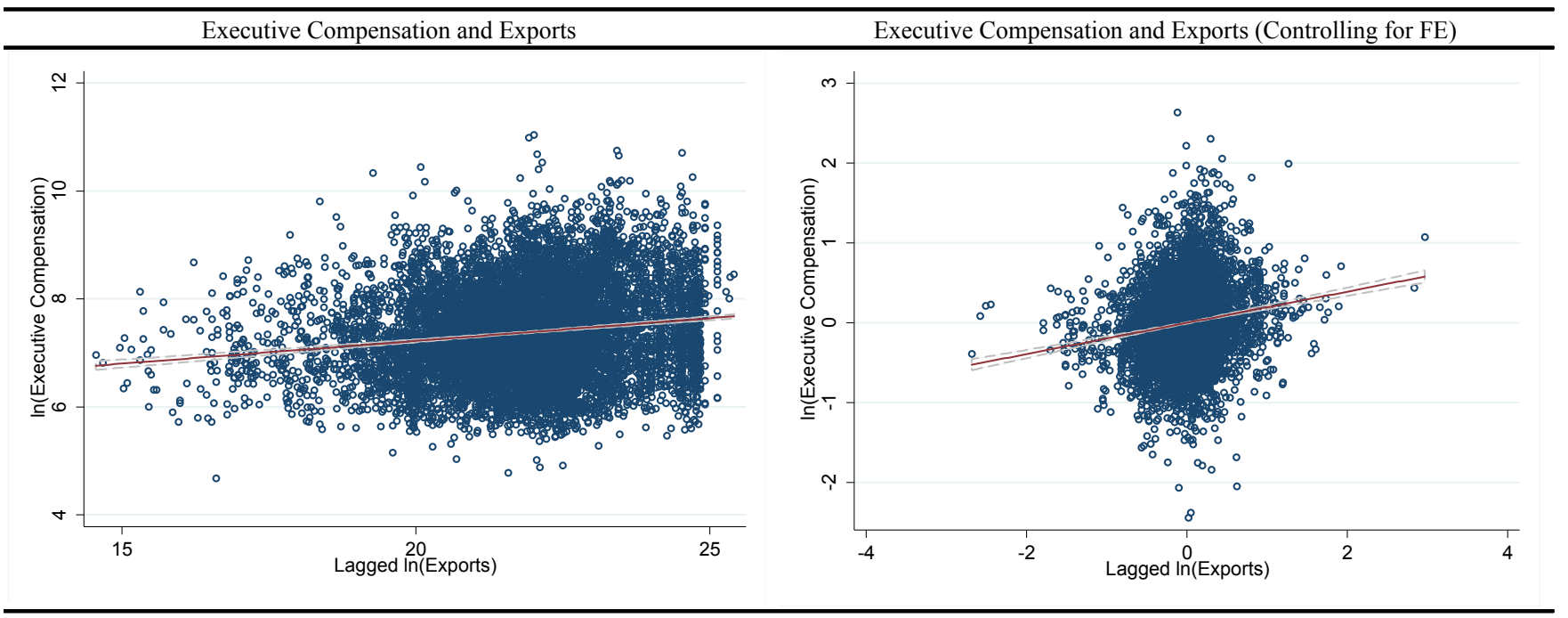

Notes: Average executive compensation (TDC1) versus lagged firm-specific exports is on the left; an analogous scatter plot is on the right after controlling for firm fixed effects and year fixed effects.

\section{Impact of Exports on Executive Pay}

This section tackles our first key question of whether globalization influences executive compensation.

\subsection{Approach}

We adopt a simple framework to examine the relationship between executive compensation and exports, given by the following equation:

(1) $\ln \operatorname{comp}_{i f n t}=\beta_{1} \ln \exp _{f t-1}+\beta_{2} \ln$ size $_{f n t-1}+\beta_{3} \ln t e c h_{f n t-1}+\beta_{4}^{\prime} X_{f n t-1}+\beta_{5}^{\prime} E_{i f n t}+\gamma_{t}+\gamma_{f}+\gamma_{n}+\varepsilon_{i f n t}$.

\footnotetext{
${ }^{30}$ We also consider within executive variation over time and find similar results (see Table 11).
} 
The dependent variable is the total compensation (TDC1) of executive $i$, at firm $f$, in industry $n$, and in year $t$. On the right side are firm specific exports (exp), firm size (size), and technology investments at the firm (tech). The vector $X$ includes other firm and industry level characteristics that may influence executive compensation, including measures of corporate governance, markups, and imports. In addition, the specification will include industry value added to control for shocks affecting compensation at the industry level. The vector $E$ includes our executive-level variables, experience, education, and gender.

Equation (1) also includes fixed effects at the year, firm, and industry level ( $\gamma_{t}, \gamma_{f}$, and $\gamma_{n}$ respectively). The inclusion of these fixed effects implies that identification comes from within-firm changes over time, which is common in the literature (e.g., Bertrand and Mullainathan 2001) and is a natural starting point given our interest in how firm-specific global shocks affect executive compensation. An alternative approach is to exploit variation over time within a given executive or job spell, and thus we show that the results are similar when executive fixed effects or executive-by-firm fixed effects are included (see Table 11). ${ }^{31}$ Robust standard errors clustered at the industry level are reported throughout and estimation is by least squares.

This section examines whether exports have a positive impact on executive compensation. To the extent that they do, subsequent sections will investigate whether this is driven by market returns to talent and actions or non-market returns such as rent capture. Growth in firm size may increase the scope of the executive's job and thus increase compensation accordingly. Similarly, new technology may enable executives to direct a larger workforce, which could increase the importance of the executive, and may raise compensation accordingly. Exports can increase firm size and lead to new technology adoption, which means that a portion of the export effect on executive compensation could operate through these firm characteristics. By including size and technology together with exports in equation (1), we ask whether exports drive up compensation conditional on these and other firm characteristics.

Rising imports have adversely affected employment opportunities of some lower-skilled U.S. workers. While the implications for executives are less clear, we do want to include imports in this specification. ${ }^{32} \mathrm{~A}$ large literature shows that executive compensation depends on firm governance, in particular on the composition of the board of directors and its relationship with top executives (see Bertrand and Mullainathan 2001). Thus, we include in equation (1) a measure of interlocked relationships between executives and the

\footnotetext{
${ }^{31}$ There is less variation over time within an executive or a job spell because the majority of executives are a top manager at only one firm in the sample and their tenure tends to be relatively short. Note that in some specifications we rely on a time-varying measure of the firm's industry, which means that including firm and industry fixed effects is important.

${ }^{32}$ Import competition may adversely affect firm performance and thus lower executive compensation but imported inputs may positively affect the firm and thus increase executive compensation. See Cuñat and Guadalupe (2009) for additional details on imports and executive compensation. In our context, we find that imports and exogenous import shocks have no impact on executive compensation (Appendix A.7).
} 
compensation committee. Finally, our analysis includes measures of firm markups, industry value added, and executive-level controls, all of which could influence executive compensation.

\section{$3.2 \quad$ Findings}

Table 2 reports the results from estimating equation (1). We begin by focusing on our measures of globalization and then we sequentially include additional covariates. After accounting for fixed effects, we find that exports have a significant positive impact on executive compensation, while the import coefficient is close to zero (and insignificant), see column 1.

Firm characteristics that are commonly found to affect executive compensation are also important in our context, as shown in column 2. First, firm size enters with a positive coefficient, reflecting that as the firm grows and the scope of the executive's job expands, compensation rises accordingly. Second, we find that technology investments also raise executive compensation (see column 2), indicating that new technologies complement executives in the production process, increase their marginal product, and thus drive up their compensation. Pivoting from explanations centered on the changing nature of the job to explanations focused on corporate governance and the degree of competition, we see that both poor governance and higher markups have a positive, although imprecisely estimated, impact on executive compensation. ${ }^{33}$

Importantly, we see that after the inclusion of these firm characteristics, exports still positively impact executive pay (column 2). ${ }^{34}$ This is an important empirical finding since it extends an existing result that firm size explains all of the recent growth in executive compensation (Gabaix and Landier 2008). While we confirm that firm size is important, our results show that globalization, as well as technology, affect executive pay conditional on firm size. Moreover, this result holds irrespective of how firm size or technology are measured (see Table A.4 for alternative firm size measures, including sales, stock price, and market value, and Table A.8 for R\&D as an alternative measure of technology). Interestingly, the export coefficient drops by $38 \%$ from column 1 to 2 , indicating that a portion of the impact of exports on executive pay operates through firm characteristics such as size. This is not surprising, given the abundance of evidence that shows trade liberalization increases firm size, and that firm size in turn influences executive pay.

Executive compensation may also vary with broader conditions, such as industry-wide productivity or price shocks. While our firm performance measures should partially account for these changing economic conditions, we also include a measure of industry value added in column 3 . The positive and significant point

\footnotetext{
${ }^{33}$ Note that firm governance may be endogenous, which we address in Appendix A.6.

${ }^{34}$ The fact that the results are significant conditional on a variety of firm characteristics indicates that the link between exports and executive compensation is not simply due to a mechanical relationship where compensation contracts reward firm performance.
} 
estimate indicates that industry shocks do influence executive compensation. Meanwhile, the coefficient on exports falls by another $32 \%$ (0.12 in column 2 to 0.08 in column 3), although it remains positive and significant. Conditional on industry value added, exports are found to be an important driver of executive pay. ${ }^{35}$

The results remain largely unchanged when we add executive-level variables, specifically experience, gender (male), and education (Dr.). All three positively affect executive compensation (column 4). Importantly, globalization, size, technology, and value added continue to be significant predictors of executive pay even after controlling for these executive characteristics. These results are both plausible and consistent with existing research, which provides support for our empirical approach and makes our new export findings all the more interesting.

To more easily compare economic magnitudes, column 5 reports normalized (beta) coefficients for the column 4 specification. We see that the export coefficient is similar in magnitude to the coefficients on size and technology investment. This indicates that exports is just as important for executive compensation as the relatively more common firm size and technology explanations. We also confirm these results are not specific to exports but reflect globalization more generally by showing that executive compensation is increasing with the firm's foreign direct investment (see Table 10). Imports, on the other hand, are found to be unimportant for executive compensation in Table 2, which likely reflects the competing effects of imported intermediate inputs and rising import competition in final goods. We conclude that globalization, and in particular access to foreign markets, is playing an important role in the rise of executive compensation.

\section{Export Shocks and Market Returns}

Our results indicate that exports are an important driver of executive pay, but can we say more on why exports increase compensation? We are particularly interested in role of market versus non-market forces in determining executive compensation. Pay may increase simply because the executive's action leads to firm expansion abroad, which clearly would be a market return to executive talent. This section tests this hypothesis by examining whether executive pay responds to exogenous export shocks that are outside of the executive's control. We then consider the possibility that even exogenous export shocks alter market conditions which in turn increases executive pay.

\footnotetext{
${ }^{35} \mathrm{~A}$ variety of extensions confirm the robustness of this result, as shown in Table 11.
} 


\subsection{Identification of Shocks}

Our firm-specific export measure partially addresses endogeneity concerns by using presample business segment shares at the firm and export growth of these products over time. However, it is still possible that industry export growth could be affected by endogenous domestic conditions, which in turn are correlated with executive compensation. Thus, we now identify an exogenous source of variation in industry exports driven by conditions in the foreign importing country.

Our strategy draws on the influential Bartik (1991) instrumental variable approach and applies it to our global trade setting. The original Bartik instrument takes presample industry employment within a city and assumes this grows at the same rate as industry employment at the national level. In line with this approach, we use presample U.S. export flows for each detailed industry and allow these trade flows to grow at an exogenous rate. Instead of using the aggregate U.S. growth rate, as suggested by Bartik's approach, we employ the more exogenous industry-level export growth in other high-income countries. ${ }^{36}$ Specifically, we multiply presample 1991 bilateral export flows for each detailed industry by the growth in industry exports from eight other countries. ${ }^{37}$ These predicted bilateral export flows are then summed across all foreign destination markets to obtain predicted U.S. exports abroad in a particular industry and year:

$$
\text { bartik_exp_iv } v_{n t}=\sum_{c}\left(\exp _{n c 1991} *\left(1+g_{n t}\right)\right),
$$

where $\exp _{n c 1991}$ is bilateral exports to country $c$ in industry $n$ in 1991 and $g_{n t}$ the growth rate of exports from other developed countries from 1991 to year $t$ in industry $n .^{38}$

This approach identifies variation in U.S. exports stemming from common import demand shocks for a particular good, as well as falling trade costs for this good. For instance, the growth of China would typically lead to an increase in exports of a particular good from both the U.S. and from other high-income countries. Importantly, by relying on variation that is unrelated to executive (or domestic firm or industry characteristics), this method eliminates fluctuations in exports that are due to managerial decisions. If

\footnotetext{
${ }^{36}$ This approach is preferred to employing aggregate U.S. export growth because patterns of globalization are highly industry-specific.

${ }^{37}$ The eight countries are Australia, Denmark, Finland, Germany, Japan, New Zealand, Spain, and Switzerland, as in Autor, Dorn, and Hanson (2013).

${ }^{38}$ One advantage of this instrument is that it can be constructed for sporadic years in which no bilateral export flows exist, since it only relies on presample bilateral exports and the industry level growth from other developed countries. Thus, the instrument is balanced and does not pick up extensive margin adjustments into or out of foreign destination markets which can occur in the actual data set and could be endogenous. It is possible to further simplify equation 2 by pulling the $g$ term through the summation, but we prefer this notational form given subsequent instrumental variable approaches utilized in section 6.4.
} 
executives are rewarded solely for their actions, then executive compensation will be unresponsive to exogenous export shocks, and our export instrumental-variables (IV) coefficient will be zero. On the other hand, if the export coefficient is positive, this will provide evidence that the executive is being rewarded for something other than their actions. Below we will also consider the possibility that export shocks alter other market conditions for executives which in turn influence their pay.

One important threat to our identification strategy is that exports from the U.S. and other high-income countries might be driven by common export supply shocks rather than common import demand shocks. This would be problematic for our instrumental-variable approach to the extent that these domestic supply shocks are also correlated with executive compensation. We address this concern in three ways. First, the construction of the instrument relies on a sample of countries that reduce this risk. For instance, Canada is not included in this comparison group, since the likelihood that it experiences similar export supply shocks as the U.S. is comparatively high. Second, we explicitly control for several of the most plausible domestic supply shocks, such as those related to scale, technological change, and industry shocks. Third, we introduce alternate instrumental variable strategies that addresses this and other threats to identification. One approach constructs an instrumental variable using fluctuations in world import demand, while another approach exploits fluctuations in exchange rates. As shown in section 6.4, these alternate instrumental variables are based on quite different identification strategies but generate similar results.

\subsection{Export Shock Findings}

Figure 5 illustrates a strong positive relationship between actual exports and the instrumental variable after accounting for firm and year fixed effects: 


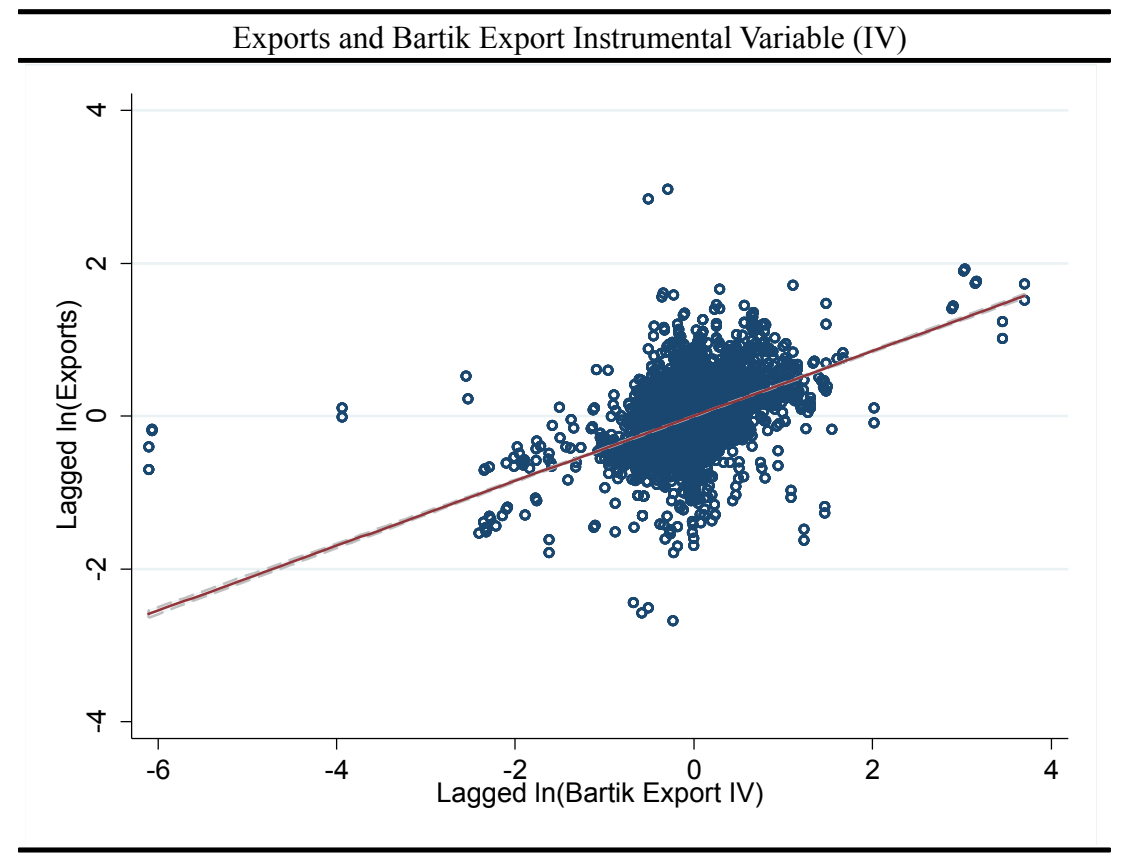

Notes: Lagged exports are plotted against the lagged Bartik export IV, controlling for firm and year fixed effects.

More formally, the bottom panel of Table 3 reports the first-stage instrumental variable results. Consistent with Figure 5, we see that the instrument is a strong predictor of actual export flows. The coefficient on the export instrument falls when we include additional firm, industry, and executive characteristics, but the instrument remains an important predictor of exports. Furthermore, the robust (Sanderson-Windmeijer, SW) F-statistics on the excluded instrument indicates relatively strong first-stages.

The upper panel of Table 3 reports the corresponding second-stage instrumental variable results. With only exports and imports included in column 1 , the coefficient on the former is 0.40 while the latter is zero. The finding that exports increase executive pay while imports do not is the same pattern we saw in the OLS results. ${ }^{39}$ Adding firm and industry characteristics reduces the export coefficient to about 0.3 , see column 2, and it stays this size when our executive-level measures are also included (column 3). By construction this empirical approach identifies fluctuations in exports that are not driven by executive, firm, or domestic industry characteristics. ${ }^{40}$ If executives are only rewarded for their actions, then their compensation will be unresponsive to these exogenous export shocks. In contrast, the findings in Table 3

\footnotetext{
${ }^{39}$ We have also explored an analogous instrumental-variable approach on the import side, but there is no evidence that import shocks significantly affect executive compensation (reported in Appendix A.7).

${ }^{40}$ These results are not sensitive to our firm size measure (employment). For instance, if sales is used to measure firm size instead, the export coefficient is 0.279 (compared to 0.300 in column 3) and the firm size coefficient is 0.069 (compared to 0.099 in column 3).
} 
show that executives are rewarded for factors that are unrelated to their behavior. Furthermore, we find that the effect is sizable: a $10 \%$ export shock leads to a $3 \%$ increase in executive pay (column 3$){ }^{41}$

If it is not returns to executive actions, then why do export shocks increase executive pay? One possibility is that executives reap non-market returns; in particular the exogenous export shock provides a rent-capture opportunity that savvy executives exploit. But this is not the only possible explanation. Even if the export shock is not caused by executive actions, it may influence executive pay through other components of what are broadly defined as market returns. For instance, a positive export shock may cause the firm to match with a more talented and highly paid executive. Relatedly, a positive export shock may cause the nature of the executive's job to change which in turn drives up compensation. While we control for some components of the executive's job, including firm size and technology, it is still possible that the nature of the job is changing in other, less observable ways. These channels will be explored in the subsequent sections.

Before proceeding, note that these instrumental variable point estimates are somewhat larger than the analogous OLS coefficients in Table 2. Taken at face value, one possible explanation is that discrimination against foreign-born executives results in lower pay but these executives are precisely the ones that are more successful at expanding abroad given their familiarity with other countries. This would introduce a spurious negative bias in the OLS coefficient, which is then addressed by identifying exogenous export shocks unrelated to the executive. More generally, while it is tempting to make inferences about the relative importance of returns to managerial decisions versus other types of returns by comparing the magnitudes of the OLS and IV estimates, the instrumental variable approach eliminates not only the endogenous returns but also measurement error and omitted variable bias. This complicates attempts to interpret the difference between the OLS and IV results.

\subsection{Market Returns through Re-Assignment}

Assignment models predict positive assortative matching where talented workers are hired by better firms (Sattinger 1975, Rosen 1981). ${ }^{42}$ Gabaix and Landier (2008) and Terviö (2008) have shown that the insights from the assignment model are useful in explaining CEO compensation. While certainly important, we are asking a more nuanced question about whether the impact of globalization on executive pay is driven by

\footnotetext{
${ }^{41}$ In the context of the optimal-contracts literature, our instrumental-variables finding is at odds with the result that optimal contracts should typically reward executives only for relative performance differences (relative performance evaluation, RPE; Holmström 1979), because, by construction, the shock was not caused by the executive. While in principle pay-for-shocks can be consistent with an optimal contractual compensation scheme (see Edmans, Gabaix, and Jenter 2017), our subsequent results suggest this is not driving our findings.

${ }^{42}$ For a recent analysis in the context of trade and inequality, see Monte (2011).
} 
assortative matching.

This section introduces elements of Gabaix and Landier (2008) to fix ideas about export shocks and market returns in a multi-executive setting. Let there be a continuum of firms $(n)$ and potential executives $(m)$ that are matched together. Low $n$ denotes a larger firm and low $m$ a more talented executive. Thus, $n$ and $m$ can be thought of as the rank of the firm and the rank of an executive, respectively. Firm $n$ has size $S(n)$ and executive $m$ has talent $T(m)$, where $S^{\prime}(n)<0, T^{\prime}(m)<0$. The executive's talent increases firm value according to:

$$
V=S(n)+c \times S(n)^{\gamma} T(m),
$$

where $\mathrm{c}>0$ is a constant. For present purposes, the key is that the multiplicative structure of firm size $S(n)$ and executive talent $T(m)$ in equation (3) implies that the productivity of talent increases with firm size. ${ }^{43}$ In our context this means that if a positive export shock increases firm size it leads to higher executive pay because the productivity of talent has increased. This structure implies that, at any point in time, a more talented executive should run a larger firm. Consequently, any changes in the relative size of the firm should lead to executive turnover. Firms that see their exports grow relative to others should attract top talent, while firms that expand more slowly should lose talented executives. ${ }^{44}$

We begin by examining the frequency of executive turnover, which is an important element of the assignment model hypothesis. Table 4 reports simple descriptive statistics, using all of the top executives in the ExecuComp data set from 1992 through 2014. We see that the vast majority of executives (92\%) work at only one firm and less than one percent of executives work at three or more firms. ${ }^{45}$ These finding are consistent with other studies that show top managers often stay at one firm for several years and rarely move directly from the top position at one firm to another (Frydman and Jenter 2010; Edmans, Gabaix, and Jenter 2017).

While executive turnover is infrequent, the most important question for our analysis is, do export shocks increase the likelihood of executive turnover in a way that influences our pay findings? As a point of reference, the left hand side of Figure 6 shows the positive relationship between export shocks and executive compensation. Then the right hand side of Figure 6 shows the relevant relationship between export shocks and the share of new executives at the firm. While there is a slight positive relationship it

\footnotetext{
${ }^{43}$ Gabaix and Landier (2008) show that if $\gamma=1$ there should be a unit elasticity of firm size and CEO pay.

${ }^{44}$ Note that our regression specification conditions on employment, so this mechanism would have to operate through a broader notion of firm size.

${ }^{45}$ If executives switch to or from firms outside this large Compustat sample, then these numbers will be different.
} 
is less positive and less significant than the relationship between export shocks and compensation on the left. ${ }^{46}$

FIGURE 6

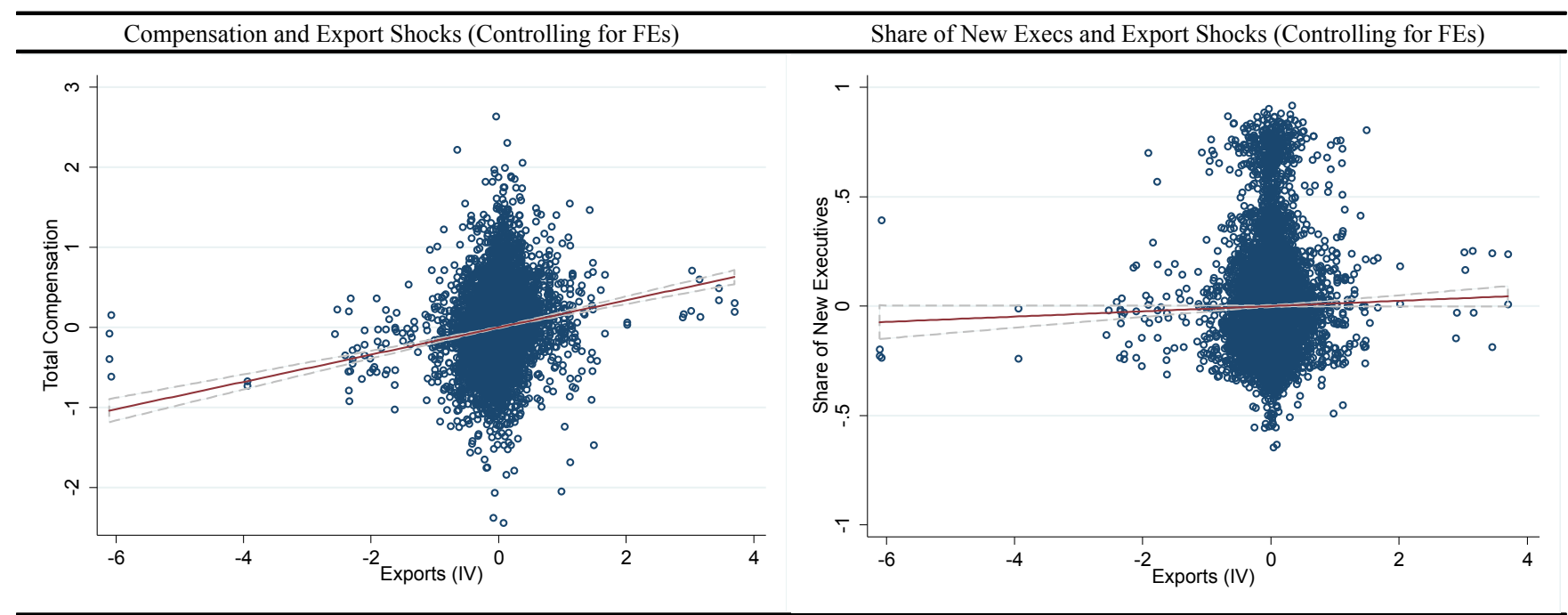

Notes: Average executive compensation (left side) and share of new top executives at the firm (right side) are plotted against lagged exports (IV). Both scatterplots control for firm and year fixed effects and plot the residuals.

We test the impact of exports on executive turnover in column 1 of Table 5 . We find that export shocks increase the probability of a new top executive at the firm, after controlling for a wide variety of other factors. However, this effect is relatively small; a ten percent export shock increases the probability of a new executive by $0.5 \%$. Column 2 re-reports our key results where we see a much larger impact of export shocks on executive pay (which is also evident in Figure 6). Column 3 shows that new executives tend to earn less than their more seasoned colleagues (see the New Exec coefficient), but importantly this has no bearing on the estimated impact of exports. Column 4 tests the assortative matching prediction by examining whether new executives hired after a positive export shock are more talented and thus earn more. The coefficient on the Export ${ }^{*}$ New Exec interaction term is positive and significant, indicating that executives hired after an export shock earn more than other newly hired executives. However, the magnitude of this effect is relatively small: a ten percent export shock leads to a newly hired executive earning $0.35 \%$ more while an existing executive earns $3 \%$ more. The assignment model is important in many settings and there is some evidence that it is playing a role in our context, however we conclude that it is not central in explaining the observed relationship between export shocks and executive compensation.

\footnotetext{
${ }^{46}$ It is possible that although executive turnover is quite rare, simply the threat of turnover may raise executive compensation. Formally, this contestable market argument would require an extension of the basic assignment model, where increasing compensation is only forthcoming if the executive actually moves. Furthermore, the threat of leaving is only credible if the executive has skills that are in demand at other firms, such as education or experience which we will explore in the next section.
} 


\subsection{Market Returns through Changing Nature of the Job}

Export shocks may also change the nature of the executive's job, thereby altering the market returns to executive talent. While we control for some key factors, such as size and technology, it is possible that globalization could affect other, less observable conditions, including the complexity of the job, competitive environment, or the organizational structure of the firm. These changing job characteristics are not driven by the executive's actions but they may nonetheless increase the demand for talented executives which will raise compensation accordingly.

The remaining columns of Table 5 provide evidence on this by examining whether global shocks disproportionately raise the compensation of the more experienced and educated executives. While experience and education do increase executive pay directly (unreported in Table 5), we do not find that export shocks disproportionately increase pay to these types of workers. None of the export interaction terms in columns 5-8 are positive and significant.

The limited evidence in Table 5 for increasing market returns in response to exogenous export shocks shows that reassignment and returns to experience and education are not central to explaining our findings. ${ }^{47}$ Of course, it is possible that export shocks alter other unobservable dimensions of executive talent. For instance, perhaps the executives that benefit from export shocks are the ones that speak foreign languages, have connections abroad, or are familiar with foreign business practices. Another possibility is that globalization increases executive compensation because of non-market forces which we examine in the next section.

\section{Export Shocks and Non-Market Returns}

After finding that the impact of global shocks on executive pay is not primarily driven by market returns, we are left with non-market returns, and in particular rent-capture, as a potential explanation. Perhaps globalization is increasing the pay of executives precisely because these workers are well placed to benefit from rent-capture opportunities. Distinguishing between market and non-market returns is important both because it informs public attitudes about rising executive compensation and because the policy response to these alternate explanations differs.

\footnotetext{
${ }^{47}$ Additional results show that export shocks do not disproportionately increase the pay of executives at larger or more technologically advanced firms (unreported).
} 


\subsection{Asymmetry}

We know from Table 3 that executives are rewarded for external export shocks that are unrelated to their actions. However, if positive export shocks and negative export shocks are equally likely and their impact symmetric, then globalization alone can not explain rising executive compensation. It turns out that positive export shocks are much more common than negative ones, in line with the increase in exports over this period (see Figures 2 and A3). ${ }^{48}$ Furthermore, there is evidence that the response of compensation to positive and negative export shocks is not symmetric. Figure 7 plots the percent change in firm-level executive pay against the percent change in our export instrumental variable. ${ }^{49}$ There is an overall positive relationship, consistent with the results from Table $3 .{ }^{50}$ However, this relationship differs depending on the sign of the shock. The kinked fitted line in Figure 7 illustrates that positive export shocks have a stronger impact on executive compensation than negative export shocks. In fact, there is no evidence that negative export shocks lower compensation at all (the slope of this line is 0.035 and is not statistically different from zero). Positive shocks, however, do significantly raise executive compensation (the slope is 0.081 with a p-value of 0.02$)$.

This asymmetry raises the possibility that rent-capture is playing a role in the relationship between exports and executive pay. In fact, executives benefiting from positive shocks but not suffering the consequences of negative shocks is exactly what one would expect if rent-capture is important. Executives successfully capture a portion of the proceeds associated with positive shocks but adverse shocks do not lead to rent-capture opportunities and thus do not affect executive pay.

\footnotetext{
${ }^{48}$ This is confirmed in Figure 7 below, where a disproportionate share of export shocks are positive (72\%) compared to negative $(28 \%)$.

${ }^{49}$ By using average firm-level executive pay, we address concerns that negative shocks could cause executives to exit the sample due to termination.

${ }^{50}$ While not shown in the figure, this relationship is positive and significant at the one percent level.
} 


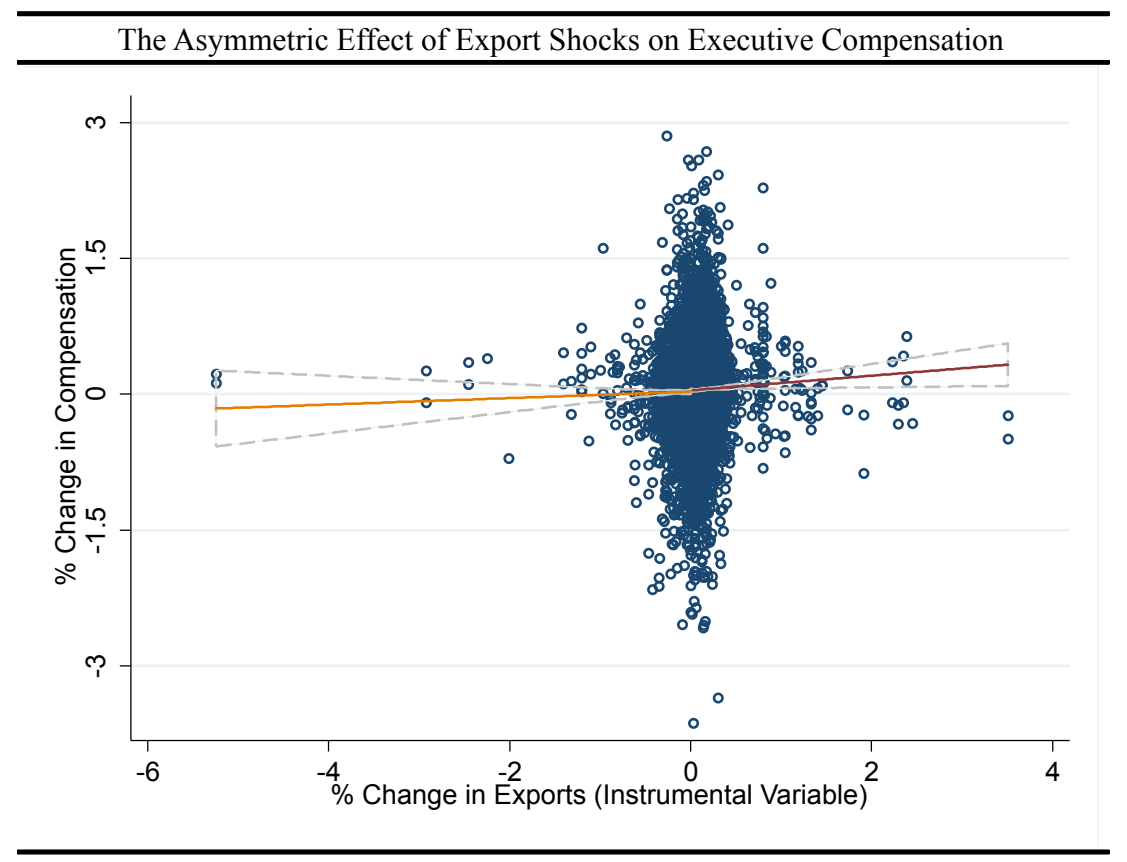

Notes: Annual percent change in average firm-level total compensation (TDC1) plotted against the annual percent change in the export instrument. Fitted lines show how compensation responds to positive and negative export shocks.

Of course, this asymmetric finding does not prove rent-capture and thus in subsequent sections we examine more formally whether non-market forces is contributing to the observed relationship between globalization and executive compensation. We employ three approaches to shed light on rent-capture. First, we examine whether exogenous export shocks disproportionately affect more discretionary types of compensation that are conducive to rent-capture. Second, we ask whether the impact of export shocks on executive pay is stronger at poor governance firms where rent-capture is more likely. Finally, we exploit the fact that some executives, in particular CEOs, have more managerial power to influence pay decisions.

\subsection{Discretionary versus Non-Discretionary Pay}

We distinguish between the following compensation categories: salary, bonuses, options, stocks, and other forms of compensation (as seen in Figure 3). We hypothesize that forms of compensation that can be adjusted in the short-term in relatively discretionary ways will be more prone to rent-capture. Thus, exogenous export shocks will tilt compensation towards less-structured and more discretionary components of pay if rent-capture is important.

Salaries are considered to be the "fixed component" in executive contracts (Murphy 1999), and in comparison bonus payments are more flexible. In Murphy's (1999) analysis the share of firms employ- 
ing discretionary elements in their bonus payments was up to $52 \%$, depending on industry (his Table 4). Furthermore, even when bonuses are based on performance measures, performance can be subjective and based on qualitative evaluations (Edmans, Gabaix, and Jenter 2017), boards can make discretionary adjustments to performance measures, boards also have discretion in allocating a fixed bonus pool across executives, and there is discretion associated with which performance measure among several will be used (Murphy 1999). Furthermore, rent-capture is common in termination payments (the 'golden handshake') and personal benefits (e.g. use of company aircraft for family travel). Both termination payments and personal benefits are in our 'other compensation' category. Overall, compensation arrangements are often camouflaged to appear as if they reward performance when in practice they may not (Bivens and Mishel 2013).

Table 6 reports results showing the impact of exogenous export shocks on different components of executive pay. For ease of comparison, column 1 re-reports the earlier results which use total compensation as the dependent variable, while columns 2-6 decompose compensation into salary, bonuses, options awarded, stocks, and other compensation. We see that exogenous export shocks have no impact on salary (column 2). In contrast, we find that exogenous export shocks have a strong positive impact on bonuses (column 3), with a coefficient almost twice as large as that for total compensation. Moreover, export shocks significantly increase other forms of compensation, including personal benefits, in column 6. Export shocks also tend to positively affect options awarded and restricted stock grants, although these coefficients are not significant at standard levels. ${ }^{51}$ Overall, these results are consistent with the hypothesis that export shocks have a stronger impact on short-run, flexible forms of compensation that are more prone to rent-capture.

Furthermore, we find that the presence of executives on the compensation committee (i.e. interlock) ${ }^{52}$ significantly increases bonus payments, while this has no impact on any of the other forms of compensation (not reported due to space constraints). The fact that poor governance is associated with larger bonuses strengthens the evidence that bonuses are more susceptible to rent-capture. It is possible that poor governance may be correlated with unobserved firm characteristics that could influence executive pay. However, after addressing the possibility that poor governance is endogenous, we find results that are somewhat larger in magnitude (Table A6). This is consistent with an endogeneity bias that attenuates the positive effect of poor governance. ${ }^{53}$

\footnotetext{
${ }^{51}$ Export shocks tend to have a larger impact on options exercised compared to options awarded (0.709 - unreported versus 0.420 - in column 4), although the former coefficient is insignificant. This provides some evidence that the executive's ability to choose when to exercise options means that this component of pay is more sensitive to export shocks.

${ }^{52}$ Or a reciprocal relationship with another firm.

${ }^{53}$ Poor governance is likely correlated with poor firm performance which all else equal (i.e. in the absence of rent-capture) will lower executive compensation. Thus, to the extent that endogeneity is an issue one would expect a negative bias in our
} 
Overall, these results indicate that the impact of export shocks on executive pay depends strongly on the specific form of compensation. Discretionary pay categories such as bonuses are increasing in the presence of export shocks, which is what one would expect if executives engage in rent-capture activities. Of course there are other reasons discretionary pay may be especially responsive (i.e. they may be more closely tied to performance measures), so additional tests for rent-capture are pursued next. Because we find the strongest effect for bonus payments, we extend this analysis in the subsequent sections. Additional results for other components of compensation are shown in Appendix A.6.

\subsection{Poor Governance}

If rent-capture is important, the impact of export shocks on bonuses should be stronger at firms with poor corporate governance. This section examines this hypothesis as another means to assess whether rent-capture is driving globalization's impact on executive pay.

To formally test this idea we interact export shocks with measures of poor corporate governance. Recall that our measures of poor governance include whether a firm has an executive that serves on the compensation committee (interlock) $)^{54}$ and whether a firm has at least three executives on the board of directors (board). The first of these measures more directly reflects the executive's impact on the pay process itself, while the second captures general executive influence over the board.

Column 1 of Table 7 re-reports our earlier bonus result, while column 2 includes the interaction of exports with interlock. We instrument for both exports and the export interaction term (using the interaction of the export instrumental variable and interlock). The positive and significant interaction coefficient indicates that export shocks disproportionately increase bonuses at poor governance firms. A 10\% export shock raises bonuses by $5.7 \%$ in general, but at poor governance firms bonuses increase by about $7.2 \%$. In other words, the impact of export shocks on executive bonuses is much stronger at firms where rent-capture is likely.

Exogenous export shocks also disproportionately increase bonuses at firms where many executives are on the board of directors, as seen in column 3. Specifically, a 10\% export shocks raises bonuses by $7.2 \%$ at these poor governance firms, compared to about $5.5 \%$ at other firms. Finally, column 4 shows that the two poor governance measures are largely orthogonal to each other and both still positively influence the relationship between export shocks and executive bonuses. We conclude that poor corporate governance is important in understanding the relationship between export shocks and executive bonuses.

results, which would work against our findings.

${ }^{54}$ Or a reciprocal relationship with another firm. 
One might be concerned that the composition and structure of the board of directors is endogenous. We have two approaches to address this issue. First, we identify long-run averages of governance that break the potential link between governance and short-run fluctuations in firm performance. In turns out that estimates using this approach are similar to or actually slightly stronger than these results (see Table A6). Second, we confirm these results with a poor governance measures that does not rely on board structure at all but rather, in the spirit of the asymmetry finding of Figure 7, examines whether pay rises when the firm's stock price falls (see Table A8). Overall, these findings provide further evidence that rent-capture plays a role in globalization's impact on executive compensation.

\subsection{Managerial Power}

Our final piece of evidence on rent-capture focuses on whether more powerful executives are the ones that disproportionately benefit from export shocks at poor governance firms. Relative to their less influential colleagues, powerful managers, such as CEOs, should be well placed to capture the rents from unexpected shocks.

The results from this analysis are presented in Table 8. In columns 1 and 2, we begin by splitting the sample into CEOs and non-CEOs and find that the linear coefficient on exports is larger for CEOs (0.73 versus 0.53). ${ }^{55}$ This indicates that managerial power matters in the context of global shocks. ${ }^{56}$ However, we are also interested in whether export shocks at poor governance firms disproportionately affect CEO pay. We see that the coefficient on the export*interlock interaction term is 0.38 for CEOs (column 1), which is substantially larger than the 0.10 coefficient for non-CEOs (in column 2). In other words, a $10 \%$ export shock increases CEO bonuses by $11 \%$ at poor governance firms but increases non-CEO bonuses by $6.3 \%$ at these same firms. In columns 3 and 4, we use the alternative board measure of poor governance instead. Again the results show that CEOs disproportionately benefit: a 10\% export shock increases CEO bonuses by almost $10 \%$ at poorly governed firms but increases non-CEO bonuses by only $6.5 \%$ at poorly governed firms. This provides further evidence that it is powerful executives who benefit most from globalization, due to their rent-capture opportunities.

Interestingly, the magnitude of the interaction effect in columns 1 and 3 indicates that having an executive on the compensation committee is more conducive to the CEO capturing rents than simply having many executives on the board of directors. ${ }^{57}$ On the right side of Table 8 , we compare results for

\footnotetext{
${ }^{55}$ Note that non-CEOs are still among the top 5 highest paid executives at the firm.

${ }^{56}$ This is not true for all firm characteristics; for example, CEOs benefit less from growth in firm size than non-CEOs according to our results (unreported).

${ }^{57}$ In unreported results, we find that both interaction coefficients remain positive and significant predictors of CEO pay
} 
the highest-paid (rank 1) and the lowest-paid (rank 5) executive at the firm according to total compensation (TDC1). We find that export shocks at interlocked firms have a larger impact on the top ranked executive compared to the fifth ranked executive (the export*interlock interaction coefficient is 0.18 versus 0.12 , with the latter coefficient insignificant). The difference between the highest paid and fifth-highest paid executive is larger when we employ the board measure of poor governance (see columns 7 and 8).

In sum, our findings present compelling evidence that rent-capture is playing a role in the link between globalization and executive compensation. First, we find in Table 6 that exogenous export shocks exclusively increase more discretionary forms of compensation (in particular bonuses), which are more conducive to rent-capture. Second, we see in Table 7 that the impact on bonuses is strongest at poor governance firms where rent-capture is more likely. Finally, the results in Table 8 show that, at these poor governance firms, it is the executives with more power that are the ones that disproportionately reap the rewards from exogenous export shocks.

\section{Extensions}

\subsection{Executive versus Average Worker Pay}

Our results indicate that exogenous export shocks increase executive compensation, but broader implications for inequality hinge on executives disproportionately benefiting from globalization. To the extent that exports increase the wages of other workers at the firm in the same way, then there would be no effect on within-firm inequality (see work by Song, Price, Guvenen, Bloom, and von Wachter 2015). Of course not all firms are equally exposed to globalization, but those that are would experience little within-firm inequality growth. One way to address this issue is by studying whether exports increase executive pay by more than average worker pay. ${ }^{58}$

Since firms are not required to report non-executive compensation in SEC filings, Compustat does not include a direct measure of wages. We therefore define average wages at the firm as labor expenses per employee, as in Bertrand and Mullainathan (1999). Unfortunately, not all firms in Compustat report labor expenses. In cases where this variable is missing, we use average labor expenses per employee at other similar firms within the same industry and year. ${ }^{59}$ This approach takes advantage of the fact that firms when included simultaneously, with the export*interlock coefficient again being larger in magnitude.

${ }^{58}$ Furthermore, if globalization is influencing executive pay through rent-capture, as our findings suggest, then focusing on average worker pay represents a quasi-placebo test. Unlike executives, rank and file workers do not have managerial power or insider relationships that will allow them to personally benefit from globalization. Thus, to the extent that rent-capture is important, it should only influence executive compensation, which provides another check of our results.

${ }^{59}$ Specifically, if firm-level average wage is missing then we use average wages at other firms within the same six-digit NAICS 
in the same year and within an industry tend to pay similar wages. While this is not a perfect method, it provides an opportunity to maintain a consistent sample of firms in light of data constraints.

Our starting point is the instrumental variable specification from before which estimates the impact of export shocks on total compensation (column 1 of Table 9). We then ask whether average worker compensation within the firm responds to globalization in the same way. Column 2 shows that export shocks have no significant impact on the average wages of workers at the firm. Finally, in column 3 we use as the dependent variable the ratio of executive to average worker compensation. The export coefficient is positive, which confirms that executives disproportionately benefit from exogenous export shocks relative to the average worker. ${ }^{60}$ In other words, globalization is leading to within-firm inequality and thus inequality between executives and the population at large.

The firm size and technology results in Table 9 are also noteworthy. Consistent with the existing literature, we find that larger firms tend to pay their executives more (column 1). However, we also find that larger firms pay their workers more too (column 2) and thus firm size does not raise the executive to worker pay ratio (column 3). These results show that while firm size increases the pay of executives, it does not lead to within-firm inequality because they also pay higher average wages too. In contrast, we find that capital expenditures increase executive compensation but decrease average worker compensation, which is consistent with skill-biased technical change complementing skilled workers and substituting for lessskilled workers. As a result, technology is found to increase the executive to worker pay gap (see column 3). Overall, these findings support our earlier results and show that both globalization and technology increase within-firm inequality.

\subsection{Foreign Direct Investment}

Given the availability of detailed trade data, we have thus far focused on exports and imports as our measures of globalization. Another component of globalization that may affect executive compensation is foreign direct investment (FDI). Firms may offshore production to foreign affiliates and thus foreign affiliate sales allow multinational firms to sell to their foreign customers without exporting. ${ }^{61}$ Unfortunately, data on foreign sales in Compustat is limited in terms of the years covered and the destination of these sales (which makes it impossible to identify foreign sales shocks using our instrumental-variable approach). However,

industry and year. If this industry-level wage is also missing, then we use average wage at the five-digit NAICS industry and so forth. Of the estimated average wage data, $22 \%$ use the six-digit NAICS average, $16 \%$ use the five-digit average, $7 \%$ use the four-digit average, $33 \%$ use the three-digit average, and $22 \%$ use the two-digit average.

${ }^{60}$ Note that the results could be attenuated because executive pay is also included in the average worker compensation in the denominator.

${ }^{61}$ There is no data on offshoring to foreign arms-length suppliers in Compustat. 
Compustat does measure foreign sales at the firm-level from 2000-2013, and data coverage becomes much better post-2010. Given the importance of FDI in the global economy, we investigate the link between foreign affiliate sales and executive compensation using this data.

Table 10 reports the relationship between foreign affiliates sales and executive compensation. The results in column 1 show that after accounting for a full set of controls and fixed effects, foreign sales raise executive compensation. The relationship between foreign affiliate sales and executive compensation strengthens when we include domestic sales (column 2). Interestingly the point estimate for foreign sales (0.038) is four times larger than the point estimate for domestic sales (0.009). Earlier results showed that global expansion increases executive compensation conditional on firm size, and the results in Table 10 provide further evidence that executive compensation is more sensitive to foreign expansion than to domestic expansion. Finally, we see that foreign affiliate sales have a stronger impact on discretionary pay categories, such as bonus payments (see column 3). Due to data constraints, these results should be interpreted with caution. However, they provide another piece of evidence that globalization, broadly defined, is indeed playing a role in the growth of executive compensation.

\subsection{Executive and Industry Fixed Effects}

Our analysis so far has exploited within-firm changes over time to identify the impact of globalization on executive compensation. This section examines the sensitivity of our results to alternate identification strategies that exploit different sources of variation. This includes pursuing estimation strategies that account for unobserved executive, executive-by-firm, and industry-by-year characteristics.

For comparison purposes, column 1 of Table 11 reports our previous estimates on the impact of export shocks on executive compensation. We drop firm fixed effects in favor of executive fixed effects in column 2. This not only changes the identifying assumptions but it also substantially increases the number of fixed effects (11,000 executives versus 800 firms). With only about four years of data for each executive, a specification with executive fixed effects is demanding and limits the variation over time used to identify the impact of globalization on executive pay. Nonetheless, in column 2 we see that export shocks have a significant positive impact on executive pay after accounting for unobserved executive characteristics. A ten percent export shocks leads to a $2.3 \%$ increase in executive pay which is similar to the $3 \%$ increase estimated in column 1.

Next, we include firm and executive fixed effects simultaneously. We find that exogenous export shocks significantly increase executive pay in column 3. If anything the estimated impact is now larger, with a 
ten percent export shock leading to a $4.6 \%$ increase in executive pay. ${ }^{62}$ Another approach is to exploit variation within each job spell, by including firm-by-executive fixed effects. Since executive turnover is limited and the vast majority of executives work for only one firm (see Table 4), the results including firm-by-executive fixed effects in column 4 are similar to those reported in column 3. Overall, these results show that exploiting variation within an executive over time leads to a similar estimated effect of exports on compensation.

Our analysis so far has dealt with potentially confounding industry conditions by controlling for industry value added and identifying variation in exports that is unrelated to domestic conditions. In column 5 , we go one step further by including industry-by-year fixed effects, where the industry is defined at the 3-digit NAICS level. The export coefficient remains positive and significant at the one percent level. Furthermore, the magnitude of this effect is similar to that found in column 1 (0.221 versus 0.300$)$. We conclude that there is little evidence that industry-by-year conditions, not captured by industry value added, are important for our results. In column 6, we combine executive fixed effects with industry-by-year fixed effects. The export coefficient falls to about 0.17 , but remains positive and significant.

Overall, Table 11 explores a variety of different identification strategies that utilize a number of different fixed effects approaches. The export coefficient varies somewhat across specifications but the range of point estimates is narrow and precisely estimated $(0.17$ to 0.46$)$. We conclude that our results are robust to employing alternate empirical specifications.

\subsection{World Import Demand and Exchange Rate IV Results}

This section examines the robustness of our results to two alternate methods of measuring exogenous export variation. While these additional approaches are conceptually distinct from our earlier instrumental variable, they all share the common goal of identifying exogenous variation in exports that is uncorrelated with executive behavior.

Our first alternate instrumental-variable approach uses world import demand (WID) shocks to identify an exogenous source of variation in U.S. exports (similar to Hummels, Jorgensen, Munch, and Xiang 2014). This method exploits the fact that shocks in a particular country likely affect the demand for goods from both the U.S. and other foreign countries. These shocks could include changes in foreign demand (due to evolving preferences or input use) or productivity shocks that alter the countries comparative advantage. Specifically, this instrument is constructed by allowing presample bilateral U.S. exports to grow at the

\footnotetext{
${ }^{62}$ However, the first-stage becomes weaker due in part to the large number of fixed effects.
} 
exogenous rate at which non-US imports into a foreign country increased within an industry. Like the Bartik instrument this approach identifies shocks to U.S. exports driven by changing foreign conditions but it identifies these shocks in a different way using different data. ${ }^{63}$ Details about the construction of this WID instrument are discussed in Appendix A.9.

Findings using this WID instrument are reported in column 1 of Table 12. The first-stage results, reported in the bottom panel, show that world import demand shocks are a positive predictor of actual U.S. export flows. The first-stage F-statistic on the excluded instrument is 9 and the associated p-value is less than one percent. The second-stage results, reported above, show that exogenous export shocks, driven by world import demand fluctuations, have a significant positive impact on executive compensation. Furthermore, the export point estimate $(0.355)$ is similar to that obtained using the Bartik instrument $(0.300)$.

Our second alternate instrumental-variable approach uses exchange rate variation to construct an export instrument (similar to Bertrand and Mullainathan 2001 and Bertrand 2004). This method exploits the fact that exchange rates fluctuate over time, defined here as the foreign country's currency per U.S. dollar. ${ }^{64}$ Furthermore, based on presample bilateral export flows, some industries will be more exposed to exchange rate fluctuations in a particular foreign country than other industries. Details about the construction of this exchange rate instrument are discussed in Appendix A.9. An advantage of this instrumental-variable approach is that exchange rate fluctuations may be harder for executives to anticipate compared to foreign import demand shocks. However, a drawback is that exchange rates may be responsive to domestic U.S. conditions, which in turn could be correlated with executive compensation.

With these considerations in mind, column 2 of Table 12 presents the instrumental variable results using this exchange rate export instrument. The first-stage results, reported in the bottom panel, show that the coefficient on the exchange rate instrument is negative and significant. As expected, an increase in the exchange rate, reported as the foreign currency per U.S. dollar, makes U.S. goods more expensive abroad and thus reduces exports. ${ }^{65}$ The second-stage results, reported above, show that exogenous export shocks driven by exchange rate fluctuations have a significant positive impact on executive compensation. The magnitude of this effect is similar to our earlier results. Overall, the findings in Table 12 are reassuring since

\footnotetext{
${ }^{63}$ The Bartik instrument uses UN Comtrade data on exports from 8 high-income countries while the WID instrument uses UN Comtrade import data reported by the foreign country.

${ }^{64}$ Nominal exchange rate data is obtained from the World Bank (WB) for numerous countries spanning the years 1990-2015. Unfortunately, the World Bank does not report exchange rates for EU countries post 1999, so instead for these EU countries we use the OECD exchange rate data that spans the entire sample. For non-EU countries that are present in both the WB and the OECD data sets, the exchange rate data are identical.

${ }^{65}$ Although the first-stage F-statistic on the instrument is weaker (7), the associated p-value is less than one percent.
} 
they indicate that our results are confirmed using a variety of different methods of identifying exogenous export shocks.

\subsection{Additional Results}

The online appendix reports a number of additional results, which due to space constraints we do not discuss in detail here. Specifically, Appendix A.1 shows the evolution of all U.S. income deciles over the last four decades, while Appendix A.2 shows that the increase in the top $1 \%$ observed in the U.S. is also qualitatively occurring in other OECD countries. The time-series variation in exports and executive compensation over our sample period is shown in Figure A3. We address concerns about the measurement of firm size by showing that our results are robust to a wide variety of other size definitions, including sales and market value, in Appendix A.4. Section A.5 examines the effect of top marginal tax rates on executive pay and reports results using a balanced sample of firms. Appendix A.6 shows how other types of compensation respond to exports at poor governance firms. This section also addresses concerns about the endogeneity of corporate governance. Findings presented in Appendix A.7 show that import shocks, constructed in an analogous way as export shocks, have no impact on executive compensation. Results using alternate measures of the firm's main industry, an alternate measure of total compensation, an alternate rent-capture measure, and an alternate technology measure are reported in section A.8. Finally, Appendix A.9 presents additional details on the alternate instrumental variable approaches.

\section{Conclusion}

We construct a panel data set spanning thousands of executives working at hundreds of major U.S. firms over the last twenty years to examine the influence of globalization on the rising compensation of business executives. Our analysis generates a number of key findings. First, through the growth in top incomes, globalization is playing a more important role in inequality than previously thought. We show that rising exports and foreign direct investment, along with firm size and technology investments, have a positive impact on executive compensation. While past studies have focused on imports or dismissed globalization's impact on top incomes based on cross-country or cross-occupation comparisons, we show using a comprehensive data set and a rigorous empirical analysis that globalization is one of the more important drivers of the recent growth of executive compensation.

Second, this finding is not simply due to talented executives successfully expanding their firms abroad and thus being more highly compensated in return. Our instrumental-variable results demonstrate that 
even export shocks, which by construction are unrelated to managerial decisions, significantly increase executive pay. There is some evidence that export shocks increase pay by improving the executive-firm match (although the magnitudes are small) and no evidence that export shocks increase the returns to talent. The observed relationship between globalization and executive pay cannot simply be explained by changing market returns.

Third, we find that rent-capture plays a role in the impact of globalization on executive compensation. Exogenous export shocks primarily affect discretionary, less-structured forms of compensation (especially bonuses), which are more conducive to rent-capture. In addition, export shocks have a larger effect on executive bonuses at poor governance firms where rent-capture is prevalent. Finally, at these poor governance firms, it is the more powerful executives, especially CEOs, that disproportionately benefit from export shocks.

Our finding that recent globalization trends have increased U.S. inequality by disproportionately raising top incomes represents an important step forward. At the same time, our results might help to explain the apparent gap between the public perception of globalization and research on globalization. In recent elections, anger about globalization has led to a populist resurgence. To the extent that top income earners disproportionately benefit from globalization in poor governance settings, these attitudes are understandable. However, our findings should not be interpreted as a rationale for protectionist policies since globalization has generated large increases in the overall standard of living. The key question for policy makers is to devise ways to address the distributional implications of globalization, such as those identified in this paper, without compromising aggregate welfare gains. 


\section{References}

[1] Alvaredo, Facundo, Anthony B. Atkinson, Thomas Piketty, and Emmanuel Saez. 2013. "The Top 1 Percent in International and Historical Perspective." Journal of Economic Perspectives, 27(3): 3-20.

[2] Antràs, Pol, and Esteban Rossi-Hansberg. 2009. "Organizations and Trade", Annual Review of Economics 1, 43-64.

[3] Autor, David H., David Dorn, and Gordon H. Hanson. 2013. "The China Syndrome: Local Labor Market Effects of Import Competition in the United States." American Economic Review, 103(6): 2121-68.

[4] Autor, David H., David Dorn, Gordon H. Hanson, and Kaveh Majlesi. 2016. "Importing Political Polarization? The Electoral Consequences of Rising Trade Exposure", NBER Working Paper \# 22637, September.

[5] Bakija, Jon, Adam Cole, and Bradley T. Heim. 2012. "Jobs and Income Growth of Top Earners and the Causes of Changing Income Inequality: Evidence from U.S. Tax Return Data.” Williams College Working Paper \#2010-22.

[6] Bartik, Timothy. 1991. Who Benefits from State and Local Economic Development Policies?, W. E. Upjohn Institute for Employment Research, Kalamazoo, MI.

[7] Bebchuk, Lucian, Alma Cohen, and Allen Ferrell. 2008. "What Matters in Corporate Governance?" The Review of Financial Studies, 22(2): 783-827.

[8] Bebchuk, Lucian, and Jesse Fried. 2004. "Pay Without Performance: The Unfulfilled Promise of Executive Compensation." Harvard University Press, Cambridge

[9] Bernard, Andrew B., J. Bradford Jensen, Stephen J. Redding, and Peter K. Schott. 2007. "Firms in International Trade." The Journal of Economic Perspectives, 21(3): 105-130.

[10] Bertrand, Marianne. 2009. "CEOs". Annual Review of Economics, 1: 121-150.

[11] Bertrand, Marianne and Sendhil Mullainathan. 2001. "Are CEOs Rewarded for Luck? The Ones without Principals Are." The Quarterly Journal of Economics, 116(3): 901-932.

[12] Bertrand, Marianne and Sendhil Mullainathan. 1999. "Is There Discretion in Wage Setting? A Test Using Takeover Legislation" RAND Journal of Economics, 33(3): 535-554.

[13] Bivens, Josh and Lawrence Mishel. 2013. "The Pay of Corporate Executives and Financial Professionals as Evidence of Rents in Top 1 Percent Incomes." Journal of Economic Perspectives, 27(3): 57-78.

[14] Bizjak, John, Michael Lemmon, and Thanh Nguyen. 2011. "Are All CEOs above Average? An Empirical Analysis of Compensation Peer Groups and Pay Design." Journal of Financial Economics, 100(3): 538-55.

[15] Blanchard, Emily and William W. Olney. 2017. "Globalization and Human Capital Investment: Export Composition Drives Educational Attainment." Journal of International Economics, 106: 165-183.

[16] Caliendo, Lorenzo, Ferdinando Monte, and Esteban Rossi-Hansberg. 2015. "The Anatomy of French Production Hierarchies." Journal of Political Economy 123(4): 809-852.

[17] Che, Yi, Yi Lu, Justin Pierce, Peter K. Schott, and Zhigang Tao. 2017. "Did Trade Liberalization with China Influence U.S. Elections?", Working Paper, Yale University, April.

[18] Chhaochharia, Vidhi, and Yaniv Grinstein (2009), "CEO Compensation and Board Structure." Journal of 
Finance 64(1): 231-261.

[19] Cuñat, Vicente and Maria Guadalupe. 2009. "Globalization and the Provision of Incentives inside the Firm: The Effect of Foreign Competition." Journal of Labor Economics, 27(2): 179-212.

[20] De Loecker, Jan and Jan Eeckhout. 2017. "The Rise of Market Power and the Macroeconomic Implications." Working Paper.

[21] Dippel, Christian, Robert Gold, Stephan Heblich, and Rodrigo Pinto. 2017. "Instrumental Variables and Causal Mechanisms: Unpacking The Effect of Trade on Workers and Voters." NBER Working Paper No. 23209.

[22] Feenstra, Robert C. and Gordon H. Hanson. 1999. "The Impact of Outsourcing and High-Technology Capital on Wages: Estimates for the United States, 1979-1990." The Quarterly Journal of Economics, 114(3): 907-40.

[23] Frankel, Jeffrey A. and David Romer. 1999. "Does Trade Cause Growth?" American Economic Review, 89(3): 379-399.

[24] Frydman, Carola. 2016. "Rising Through the Ranks: The Evolution of the Market for Corporate Executives, 1936-2003". Forthcoming, Management Science.

[25] Frydman, Carola and Dirk Jenter. 2010. "CEO Compensation." Annual Review of Financial Economics, 2: $75-102$.

[26] Frydman, Carola and Raven E. Saks. 2010. "Executive Compensation: A New View from a Long-Term Perspective, 1936-2005." The Review of Financial Studies, 23(5): 2099-2138.

[27] Garicano, Luis, and Esteban Rossi-Hansberg. 2006. "Organization and Inequality in a Knowledge Economy", The Quarterly Journal of Economics 121(4): 1383-1435.

[28] Gabaix, Xavier, and Augustin Landier. 2008. "Why has CEO Pay Increased so Much?" The Quarterly Journal of Economics, 123(1): 49-100.

[29] Garicano, Luis and Esteban Rossi-Hansberg. 2006. "Organization and Inequality in a Knowledge Economy." The Quarterly Journal of Economics, 121(4): 1383-1435.

[30] Garvey, Gerald T., and Todd T. Milbourn. 2006. "Asymmetric Benchmarking in Compensation: Executives are Rewarded for Good Luck but not Penalized for Bad". Journal of Financial Economics 82:197-225

[31] Gibbons, Robert, and Kevin J. Murphy. 1990. "Relative Performance Evaluation for Chief Executive Officers." ILR Review 43(3): 30-51.

[32] Gillan, Stuart L., Jay C. Hartzell, and Robert Parrino. 2009. "Explicit versus Implicit Contracts: Evidence from CEO Employment Agreements." Journal of Finance, 64(4): 1629-1655.

[33] Gompers, Paul, Joy Ishii, and Andrew Metrick. 2003. "Corporate Governance and Equity Prices." The Quarterly Journal of Economics, 118(1): 107-156.

[34] Gordon, Robert J., and Ian Dew-Becker. 2008. "Controversies about the Rise of American Inequality: A Survey". NBER Working Paper \#13982, May.

[35] Guvenen, Fatih and Greg Kaplan. 2017. "Top Income Inequality in the 21st Century: Some Cautionary Notes." NBER Working Paper No. 23321. 
[36] Guvenen, Fatih, Greg Kaplan, and Jae Song. 2014. "The Glass Ceiling and The Paper Floor: Gender Differences among Top Earners, 1981-2012." NBER Working Paper No. 20560.

[37] Haskel, Jonathan E., Sonia C. Pereira, and Matthew J. Slaughter. 2007. "Does Inward Foreign Direct Investment Boost the Productivity of Domestic Firms?" The Review of Economics and Statistics, 89(3): 482-496.

[38] Hermalin, Benjamin E. 2005. "Trends in Corporate Governance." The Journal of Finance, 60(5): 2351-2384.

[39] Himmelberg, Charles P., and R. Glenn Hubbard. 2000. "Incentive Pay and the Market for CEOs: An Analysis of Pay-for-Performance Sensitivity," mimeo, Columbia University.

[40] Holmström, Bengt. 1979. "Moral Hazard and Observability." The Bell Journal of Economics, 10(1): 74-91.

[41] Hummels, David, Rasmus Jorgensen, Jakob Munch, and Chong Xiang. 2014. "The Wage Effects of Offshoring: Evidence from Danish Matched Worker-Firm Data." American Economic Review, 104(6): 1597-1629.

[42] Katz, Lawrence F., and David Autor. 1999. "Changes in the Wage Structure and Earnings Inequality." In Handbook of Labor Economics, Vol. 3A, edited by Orley Ashenfelter and David Card, 1463-555. Amsterdam: Elsevier Science.

[43] Kaplan, Steven N., and Joshua Rauh. 2013. "It's the Market: The Broad-Based Rise in the Return to Top Talent" The Journal of Economic Perspectives, 27(3): 35-56.

[44] Kaplan, Steven N., and Joshua Rauh. 2010. "Wall Street and Main Street: What Contributes to the Rise in the Highest Incomes?" The Review of Financial Studies, 23(3):1004-1050.

[45] Keller, Wolfgang, and Hale Utar. 2016. "International Trade and Job Polarization: Evidence at the Worker Level", NBER Working Paper \# 22315, June.

[46] Keller, Wolfgang, and Stephen R. Yeaple. 2009. "Multinational Enterprises, International Trade, and Productivity Growth: Firm-Level Evidence from the United States." The Review of Economics and Statistics, 91(4): 821-831.

[47] Krugman, Paul R. 2008. "Trade and Wages, Reconsidered." Brookings Papers on Economic Activity (1): 103-38.

[48] Ma, Lin. 2015. "Globalization and Top Income Shares." National University of Singapore, mimeo.

[49] Melitz, Marc J. 2003. "The Impact of Trade on Intra-Industry Reallocations and Aggregate Industry Productivity." Econometrica, 71(6): 1695-1725.

[50] Monte, Ferdinando. 2011. "Skill Bias, Trade and Wage Dispersion." Journal of International Economics, 83(2): $202-218$.

[51] Murphy, Kevin J. 1999. "Executive Compensation." in Handbook of Labor Economics, Vol. 3b, Orley Ashenfelter and David Card, eds. (New York/Oxford; Elsevier Science/North Holland).

[52] Murphy, Kevin J., and Jan Zabojnik. 2006. "Managerial capital and the market for CEOs." Working Paper, University of Southern California.

[53] Murphy, Kevin J., and Jan Zabojnik. 2004. "CEO pay and appointments: a market-based explanation for recent trends." American Economic Review 94:192-96.

[54] Pierce, Justin R. and Peter K. Schott. 2016. "The Surprisingly Swift Decline of US Manufacturing Employment." 
American Economic Review, 106(7): 1632-62.

[55] Piketty, Thomas, and Emmanuel Saez. 2003. "Income Inequality in the United States, 1913-1998." The Quarterly Journal of Economics, 118(1): 1-41.

[56] Piketty, Thomas, and Emmanuel Saez. 2006. "The Evolution of Top Incomes: A Historical and International Perspective" American Economic Review, 96: 200-205.

[57] Piketty, Thomas, Emmanuel Saez, and Stefanie Stantcheva. 2014. "Optimal Taxation of Top Labor Incomes: A Tale of Three Elasticities." American Economic Journal: Economic Policy, 6(1): 230-271.

[58] Piketty, Thomas, Emmanuel Saez, and Gabriel Zucman. 2017. "Distributional National Accounts: Methods and Estimates for the United States." NBER Working Paper No. 22945.

[59] Rajan, Raghuram, and Julie Wulf. 2006. "The Flattening Firm: Evidence From Panel Data on the Changing Nature of Corporate Hierarchies." Review of Economics and Statistics 88(4): 759-773.

[60] Rosen, Sherwin. 1981. "The Economics of Superstars." The American Economic Review, 71(5): 845-858.

[61] Sattinger, Michael. 1975. "Comparative Advantage and the Distribution of Earnings and Abilities." Econometrica, 43(3): 455-68.

[62] Schott, Peter K. 2008. "The Relative Sophistication of Chinese Exports." Economic Policy: 5-49.

[63] Song, Jae, David J. Price, Fatih Guvenen, Nicholas Bloom, and Till von Wachter. 2015. "Firming Up Inequality." NBER Working Paper No. 21199.

[64] Terviö, Marko. 2008. "The Difference That CEOs Make: An Assignment Model Approach." The American Economic Review, 98(3): 642-668.

[65] Trefler, Daniel. 2004. "The Long and Short of the Canada-U.S. Free Trade Agreement." The American Economic Review, 94(4): 870-895. 
TABLE 1

Summary Statistics

\begin{tabular}{lccc}
\hline & Obs & Mean & Std. Dev. \\
\hline Compensation Variables: & & & \\
ln (Executive Compensation) & 48,705 & 7.38 & 1.02 \\
$\ln$ (Salary) & 48,705 & 6.10 & 0.62 \\
$\ln$ (Bonus) & 48,705 & 5.03 & 2.24 \\
$\ln$ (Options) & 48,705 & 4.90 & 2.80 \\
$\ln$ (Stocks) & 48,705 & 2.64 & 2.98 \\
$\ln$ (Other Compensation) & 48,705 & 3.56 & 1.67 \\
Independent Variables: & & & \\
$\ln$ (Exports)-1 & 48,705 & 21.84 & 1.56 \\
$\ln$ (Imports)-1 & 48,218 & 22.07 & 2.23 \\
$\ln$ (Employment)-1 & 48,355 & 8.40 & 1.66 \\
$\ln$ (Capital Expenditure)-1 & 48,245 & 18.17 & 1.88 \\
Interlock & 48,705 & 0.06 & 0.24 \\
$\ln$ (Markups)-1 & 48,665 & 0.95 & 0.33 \\
$\ln$ (Ind Value Added) -1 & 48,092 & 11.89 & 0.64 \\
Board & 48,705 & 0.16 & 0.36 \\
Experience & 48,705 & 4.67 & 3.64 \\
Male & 48,705 & 0.96 & 0.19 \\
Dr. & 48,705 & 0.03 & 0.17 \\
\# of Executives & 10,953 & & \\
\# of Firms & 798 & & \\
\hline Notes Total Executve & & & \\
\hline
\end{tabular}

Notes: Total Executive Compensation (TDC1) includes Salary, Bonus + Long Term Incentive Plans (LTIP), Options Awarded, Stocks, and Other types of compensation. Firm Specific Exports are constructed using the firm's presample business segments and 6-digit NAICS export data.

Employment, Capital Expenditure, Interlock, Markups, and Board are measured at the firm level. Imports and Value Added are measured at the NAICS level (6-digit and 3-digit respectively). Experience, Male, and Dr. are measured at the executive level. 
TABLE 2

The Impact of Exports on Executive Compensation

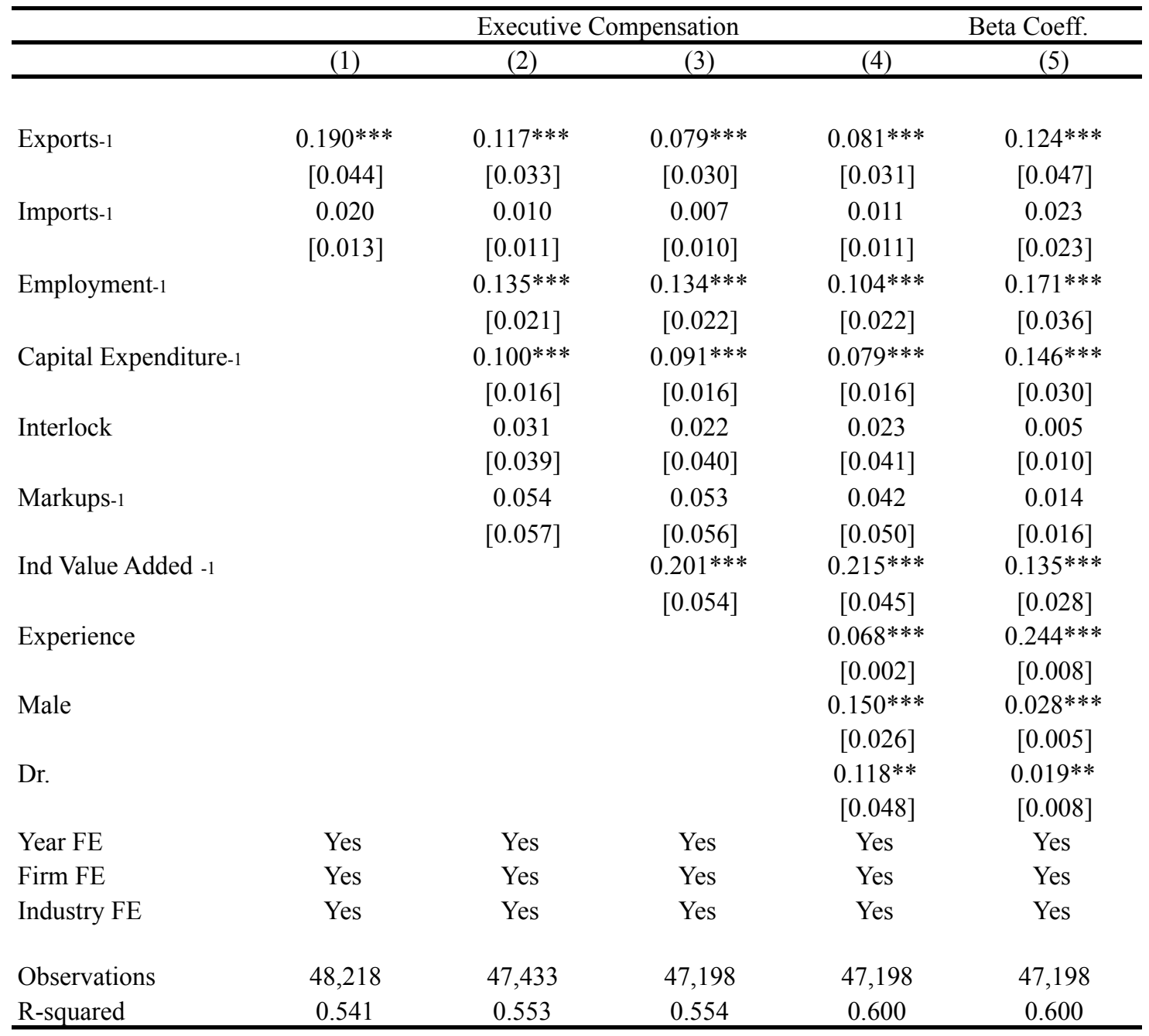

Notes: The dependent variable is the log of total compensation (TDC1) of the executive. Estimation by OLS. Exports, imports, employment, capital expenditure, markups, and industry value added are all in logs. Column 5 reports the Beta Coefficients after standardizing all variables to have a mean of 0 and a standard deviation of 1 . Robust standard errors clustered at the industry level in brackets. *** $\mathrm{p}<0.01$, $* * \mathrm{p}<0.05, * \mathrm{p}<0.1$. 
TABLE 3

The Impact of Export Shocks on Executive Compensation

\begin{tabular}{|c|c|c|c|}
\hline & \multicolumn{3}{|c|}{ Executive Compensation } \\
\hline & (1) & $(2)$ & (3) \\
\hline \multirow[t]{2}{*}{ Exports-1 } & $0.399 * * *$ & $0.289 * * *$ & $0.300 * * *$ \\
\hline & {$[0.057]$} & {$[0.072]$} & {$[0.062]$} \\
\hline \multirow[t]{2}{*}{ Imports- 1} & 0.000 & -0.004 & 0.000 \\
\hline & {$[0.011]$} & {$[0.010]$} & {$[0.010]$} \\
\hline Firm Controls & No & Yes & Yes \\
\hline Industry Controls & No & Yes & Yes \\
\hline Executive Controls & No & No & Yes \\
\hline Year FE & Yes & Yes & Yes \\
\hline Firm FE & Yes & Yes & Yes \\
\hline Industry FE & Yes & Yes & Yes \\
\hline Observations & 46,828 & 46,068 & 46,068 \\
\hline R-squared & 0.536 & 0.549 & 0.595 \\
\hline \multicolumn{4}{|l|}{ First Stage Results: } \\
\hline \multirow[t]{2}{*}{ Export IV-1 } & $0.403 * * *$ & $0.281 * * *$ & $0.280 * * *$ \\
\hline & {$[0.072]$} & {$[0.055]$} & {$[0.055]$} \\
\hline SW F-Stat on Instrument & 31.55 & 26.40 & 26.35 \\
\hline SW F p-value & 0.000 & 0.000 & 0.000 \\
\hline
\end{tabular}

Notes: First and second stage of two-stage least squares regressions. The dependent variable in the second stage is the log of total executive compensation (TCD1) and in the first stage it is lagged log exports. Exports, imports, employment, capital expenditure, markups, and industry value added are all in logs. Robust standard errors clustered at the industry level in brackets. $* * * \mathrm{p}<0.01, * * \mathrm{p}<0.05, * \mathrm{p}<0.1$. 
TABLE 4

Executive Turnover

\begin{tabular}{ccc}
\hline \# of Employers per Executive & \# of Executives & Percent of Sample \\
\hline & & \\
2 & 38,024 & 92.07 \\
3 & 2,888 & 6.99 \\
4 & 329 & 0.80 \\
5 & 47 & 0.11 \\
6 & 9 & 0.02 \\
& 2 & 0.00 \\
\hline
\end{tabular}

Notes: This table shows the number of S\&P firms that each of the executives in the full ExecuComp sample have worked at. 


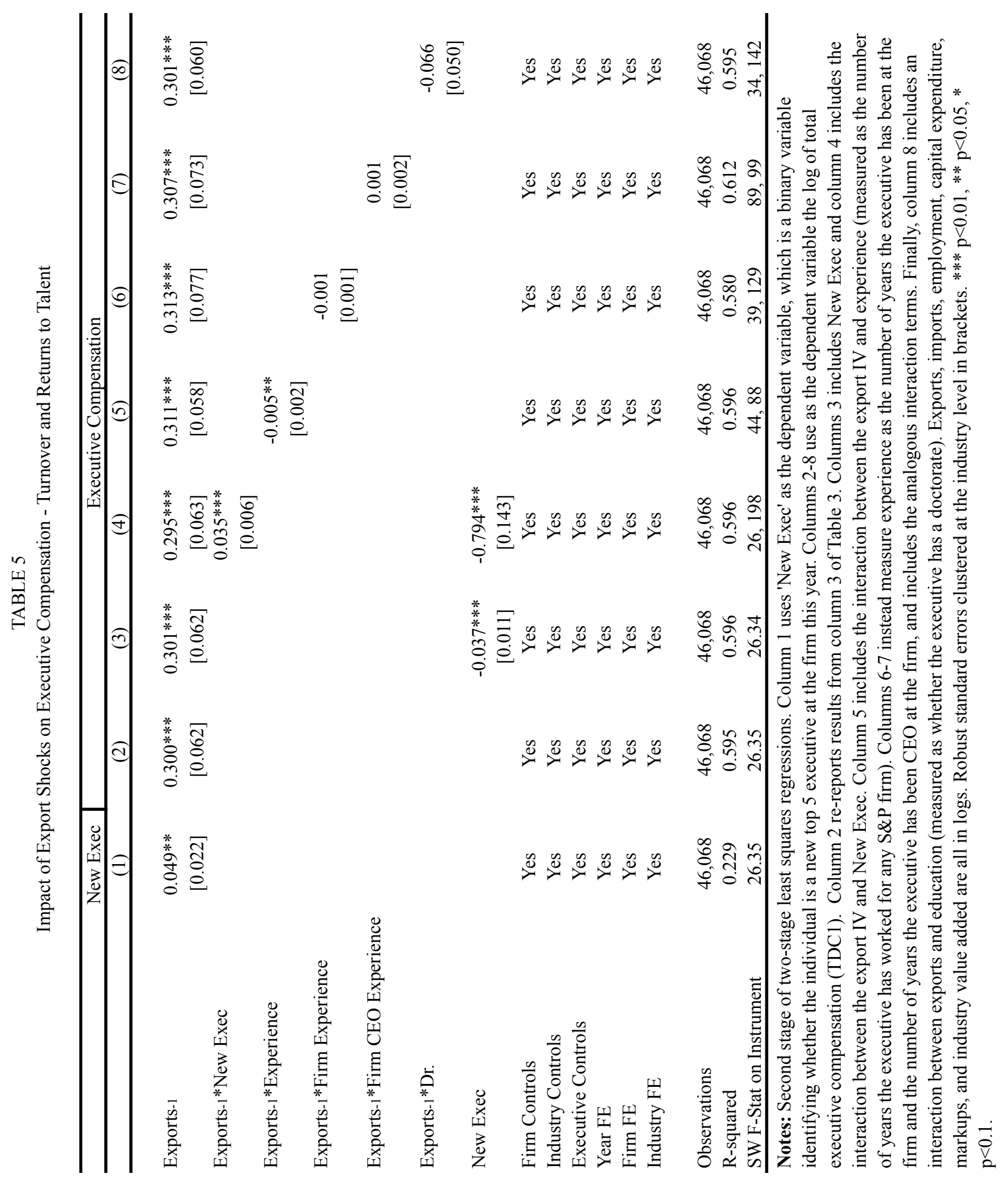




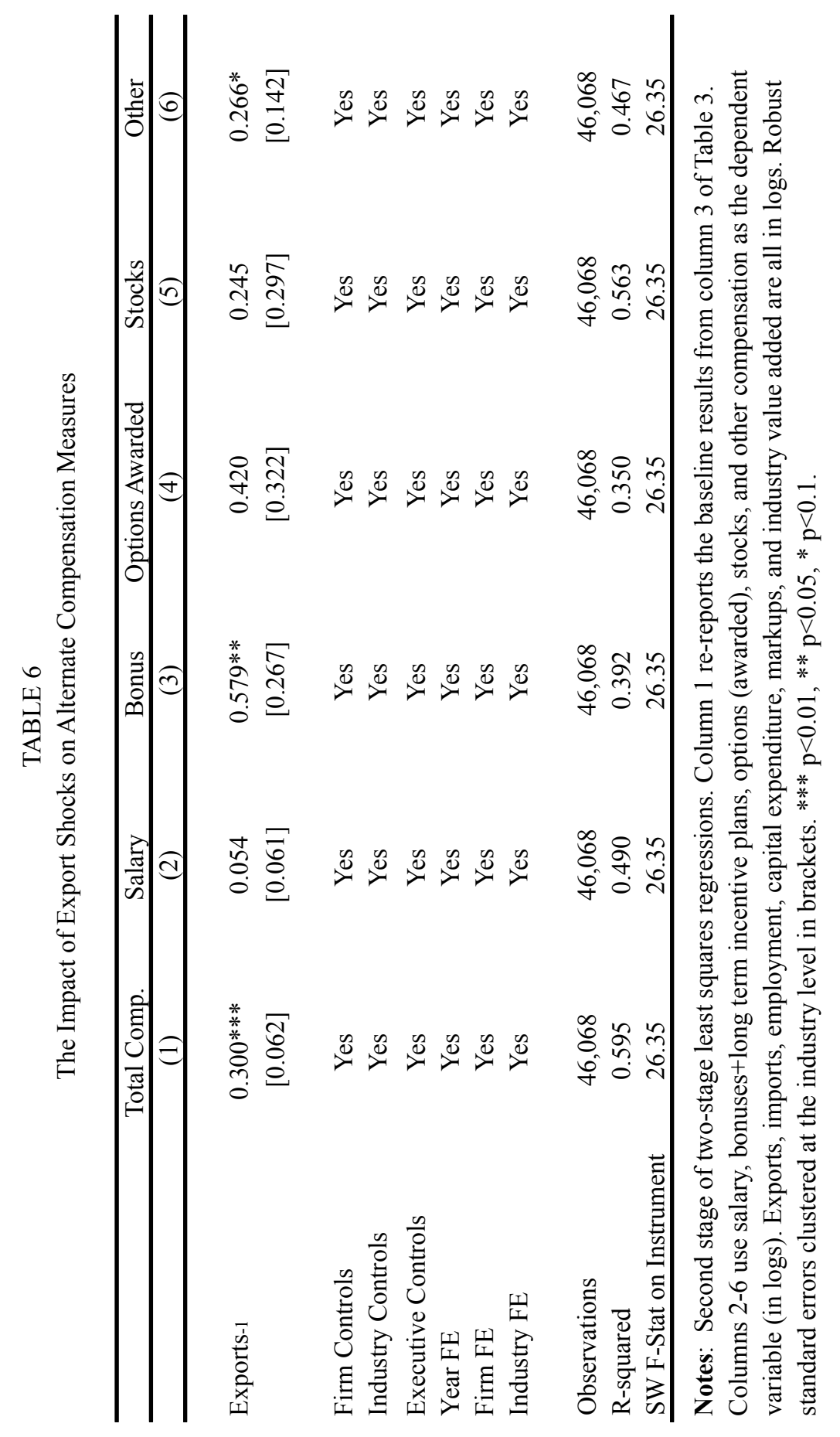


TABLE 7

The Impact of Export Shocks on Bonuses at Poor Governance Firms

\begin{tabular}{|c|c|c|c|c|}
\hline & \multicolumn{4}{|c|}{ Executive Bonuses } \\
\hline & (1) & $(2)$ & $(3)$ & (4) \\
\hline \multirow[t]{2}{*}{ Exports-1 } & $0.579 * *$ & $0.566 * *$ & $0.547 * *$ & $0.540 * *$ \\
\hline & {$[0.267]$} & {$[0.263]$} & {$[0.267]$} & {$[0.264]$} \\
\hline \multirow[t]{2}{*}{ Exports- $1 *$ Interlock } & & $0.155 * *$ & & $0.124^{*}$ \\
\hline & & {$[0.068]$} & & {$[0.068]$} \\
\hline \multirow[t]{2}{*}{ Exports- $1 *$ Board } & & & $0.171 * *$ & $0.162 * *$ \\
\hline & & & {$[0.070]$} & {$[0.073]$} \\
\hline Firm Controls & Yes & Yes & Yes & Yes \\
\hline Industry Controls & Yes & Yes & Yes & Yes \\
\hline Executive Controls & Yes & Yes & Yes & Yes \\
\hline Year FE & Yes & Yes & Yes & Yes \\
\hline Firm FE & Yes & Yes & Yes & Yes \\
\hline Industry FE & Yes & Yes & Yes & Yes \\
\hline Observations & 46,068 & 46,068 & 46,068 & 46,068 \\
\hline R-squared & 0.392 & 0.392 & 0.392 & 0.392 \\
\hline SW F-Stat on Instrument & 26.35 & 27,238 & 26,81 & $27,319,102$ \\
\hline
\end{tabular}

Notes: Second stage of two-stage least squares regressions. Dependent variable in all columns is the $\log$ of bonuses. Exports and the interaction terms are instrumented throughout using the Bartik style instrument and the interaction of this instrument and the poor governance variables. Exports, imports, employment, capital expenditure, markups, and industry value added are all in logs. Column 3 includes uniteracted Board instead of Interlock and column 4 includes both Board and

Interlock . Robust standard errors clustered at the industry level in brackets. $* * * \mathrm{p}<0.01, * * \mathrm{p}<0.05$, $* \mathrm{p}<0.1$. 


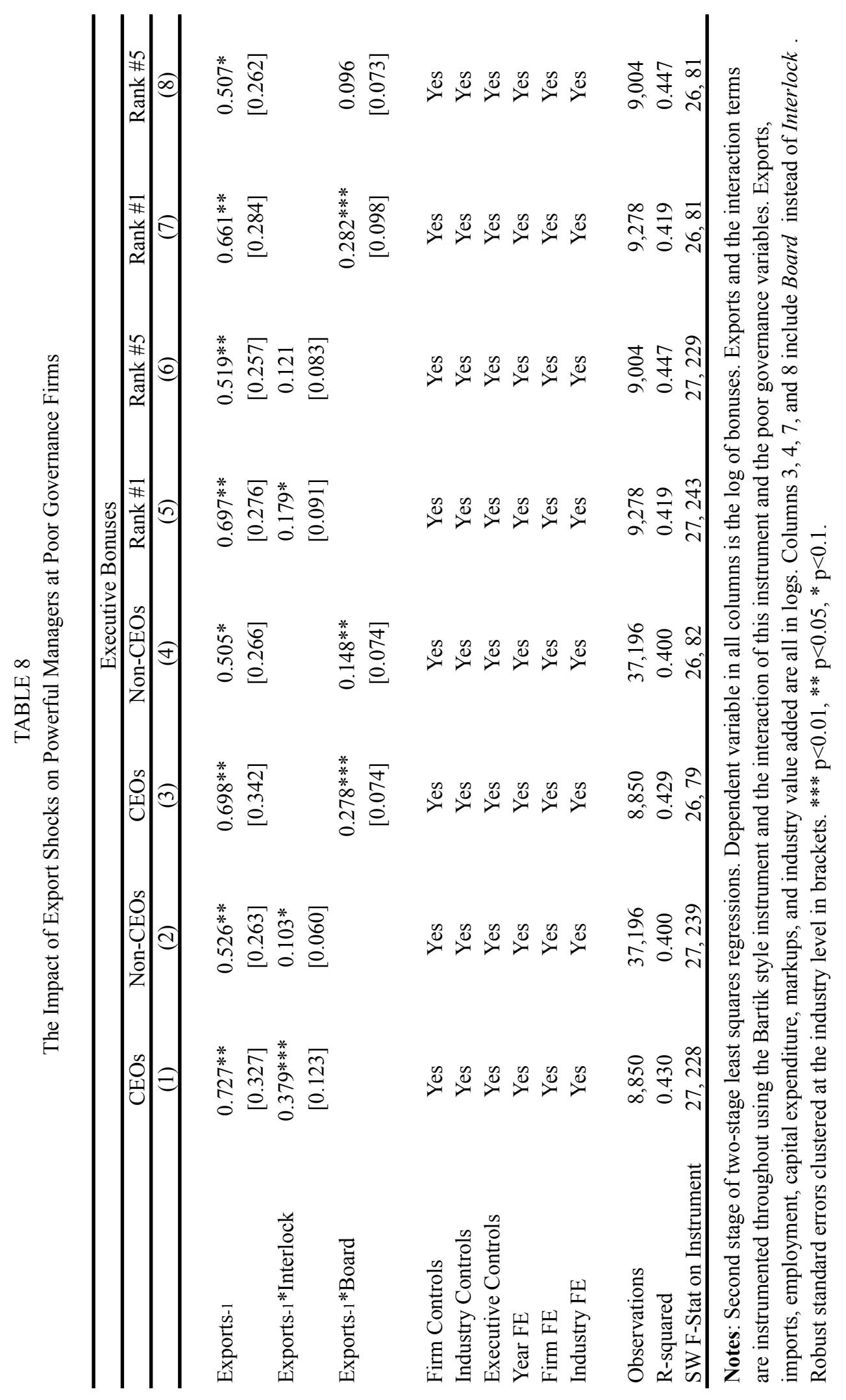


TABLE 9

The Impact of Export Shocks on Executive and Average Worker Compensation

\begin{tabular}{lccc}
\hline & Execu Comp & Avg Worker Comp & Exec / Worker Ratio \\
\hline & $(1)$ & $(2)$ & $(3)$ \\
Exports-1 & & & \\
& $0.300^{* * *}$ & -0.401 & $0.703^{*}$ \\
Employment-1 & {$[0.062]$} & {$[0.339]$} & {$[0.372]$} \\
& $0.099^{* * *}$ & $0.148^{* * *}$ & -0.049 \\
Capital Expenditure-1 & {$[0.022]$} & {$[0.036]$} & {$[0.048]$} \\
& $0.066^{* * *}$ & $-0.142^{* * *}$ & $0.211^{* * *}$ \\
& {$[0.015]$} & {$[0.035]$} & {$[0.045]$} \\
Other Firm Controls & & & \\
Industry Controls & Yes & Yes & Yes \\
Executive Controls & Yes & Yes & Yes \\
Year FE & Yes & Yes & Yes \\
Firm FE & Yes & Yes & Yes \\
Industry FE & Yes & Yes & Yes \\
& Yes & Yes & \\
Observations & & & 45,683 \\
R-squared & 46,068 & 9,201 & 0.431 \\
SW F-Stat on Instrument & 0.595 & 0.288 & 26.13 \\
\hline
\end{tabular}

Notes: Second stage of two-stage least squares regressions. Dependent variable is the log of total executive compensation (TDC1) in column 1, the average worker compensation at the firm in column 2, and the ratio of total executive compensation (TDC1) to average worker compensation in column 3. Average worker compensation is measured as the firm's labor expenses per employee, and if this data is missing, by the detailed industry average of compensation per employee.

Exports, imports, employment, capital expenditure, markups, and industry value added are all in logs. Robust standard errors clustered at the industry level in brackets. $* * * \mathrm{p}<0.01, * * \mathrm{p}<0.05, *$ $\mathrm{p}<0.1$. 
TABLE 10

The Impact of Foreign Affiliate Sales on Executive Compensation

\begin{tabular}{lcccc}
\hline & \multicolumn{2}{c}{ Executive Compensation } & Bonuses \\
\hline & $(1)$ & $(2)$ & $(3)$ \\
Foreign Sales-1 & & & \\
& $0.025^{* *}$ & $0.038^{* * *}$ & $0.106^{* *}$ \\
Domestic Sales-1 & {$[0.012]$} & {$[0.013]$} & {$[0.047]$} \\
& & $0.009^{* * *}$ & $0.043^{* * *}$ \\
Firm Controls & & {$[0.003]$} & {$[0.017]$} \\
Industry Controls & & & \\
Executive Controls & Yes & Yes & Yes \\
Year FE & Yes & Yes & Yes \\
Firm FE & Yes & Yes & Yes \\
Industry FE & Yes & Yes & Yes \\
& Yes & Yes & Yes \\
Observations & Yes & Yes & 11,633 \\
R-squared & & & 0.492 \\
\hline
\end{tabular}

Notes: Dependent variable is log total executive compensation (TDC1) in columns 1-2, and $\log$ executive bonuses in column 3. Estimation by OLS. Years included are 2000-2013 based on available foreign sales data (pre-2010 data is more limited). Foreign sales, domestic sales, employment, capital expenditure, markups, and industry value added are all in logs. Robust standard errors clustered at the industry level in brackets. ${ }^{* * *} \mathrm{p}<0.01$, $* * \mathrm{p}<0.05, * \mathrm{p}<0.1$. 


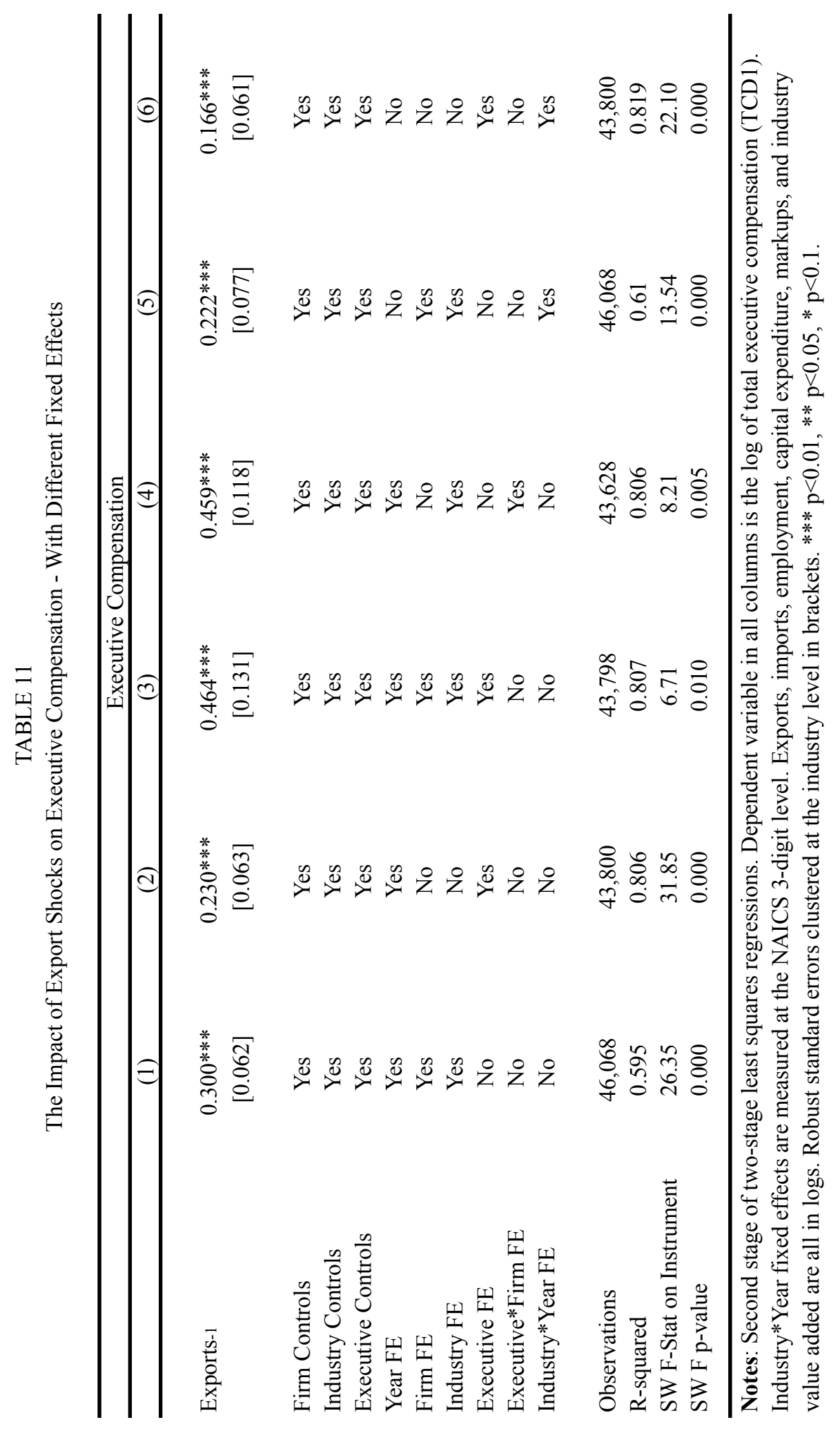


TABLE 12

The Impact of Export Shocks on Executive Compensation - Alternative Instrumental Variable Models

\begin{tabular}{|c|c|c|}
\hline & World Import Demand IV & Exchange Rate IV \\
\hline & $(1)$ & $(2)$ \\
\hline Exports-1 & $\begin{array}{c}0.354 * * * \\
{[0.097]}\end{array}$ & $\begin{array}{c}0.368 * \\
{[0.206]}\end{array}$ \\
\hline Firm Controls & Yes & Yes \\
\hline Industry Controls & Yes & Yes \\
\hline Executive Controls & Yes & Yes \\
\hline Year FE & Yes & Yes \\
\hline Firm FE & Yes & Yes \\
\hline Industry FE & Yes & Yes \\
\hline Observations & 44,894 & 44,894 \\
\hline R-squared & 0.595 & 0.594 \\
\hline \multicolumn{3}{|l|}{ First Stage Results: } \\
\hline WID IV-1 & $\begin{array}{c}0.047 * * * \\
{[0.016]}\end{array}$ & \\
\hline Ex Rate IV-1 & & $\begin{array}{c}-0.027 * * * \\
{[0.010]}\end{array}$ \\
\hline SW F-Stat on Instrument & 8.95 & 7.00 \\
\hline SW F p-value & 0.003 & 0.009 \\
\hline
\end{tabular}

Notes: First and second stage results of two-stage least squares regressions. The dependent variable in the second stage is the log of executive compensation (TCD1) and in the first stage it is the lagged log of exports. Column 1 utilizes an instrument that is constructed using world import demand (excluding U.S. imports) and presample bilateral export flows. Column 2 utilizes an instrument that is constructed using exchange rate variation and presample bilateral export flows. Firm exposure to export shocks is measured in their main business segment industry. Exports, imports, employment, capital expenditure, markups, and industry value added are all in logs. Robust standard errors clustered at the industry level in brackets. $* * * \mathrm{p}<0.01, * * \mathrm{p}<0.05, * \mathrm{p}<0.1$. 
ONLINE APPENDIX FOR REFEREES ONLY 


\section{A Appendix Table of Contents - Overview}

A.1 Evolution of All U.S. Income Deciles

- Extension of Figure 1

A.2 Top $1 \%$ in Other OECD Countries

- Rising Top $1 \%$ income share across a variety of countries

A.3 Time-Series Variation

- Changes in executive compensation and exports over our sample

\section{A.4 Measuring Firm Size}

- Results with employment, sales, assets, stock price, and market value

A.5 Top Tax Rates and Sample Selection

- Results including state top marginal tax rates and a balanced sample of firms

A.6 Poor Governance Details

- Impact of export shocks on compensation components at poor governance firms

- Results that eliminate endogenous short-run changes in board structure

A.7 Import Shocks

- Evidence on whether executive pay responds to import shocks

A.8 Additional Sensitivity Findings

- Trade exposure definition

- Alternate measures

A.9 Additional Instrumental Variable Details 


\section{A.1 Evolution of All U.S. Income Deciles}

Figure 1 illustrates a dramatic increase in the share of total U.S. income going to the top 1\% of earners over the last four decades, while the other two deciles remain essentially flat. To ensure these relationships are not an artifact of the income groups selected, in Figure A1 we report all the U.S. income deciles. We see that the share of income going to the top decile of U.S. earners has increased from about $30 \%$ to almost $50 \%$ over the last forty years. The other nine deciles all have income shares that are well below $20 \%$ and they have experienced a similar decline over the last forty years. We conclude that regardless of how one calculates it, growth in inequality in the U.S. is driven by the rapid increase in top incomes.

FIGURE A1

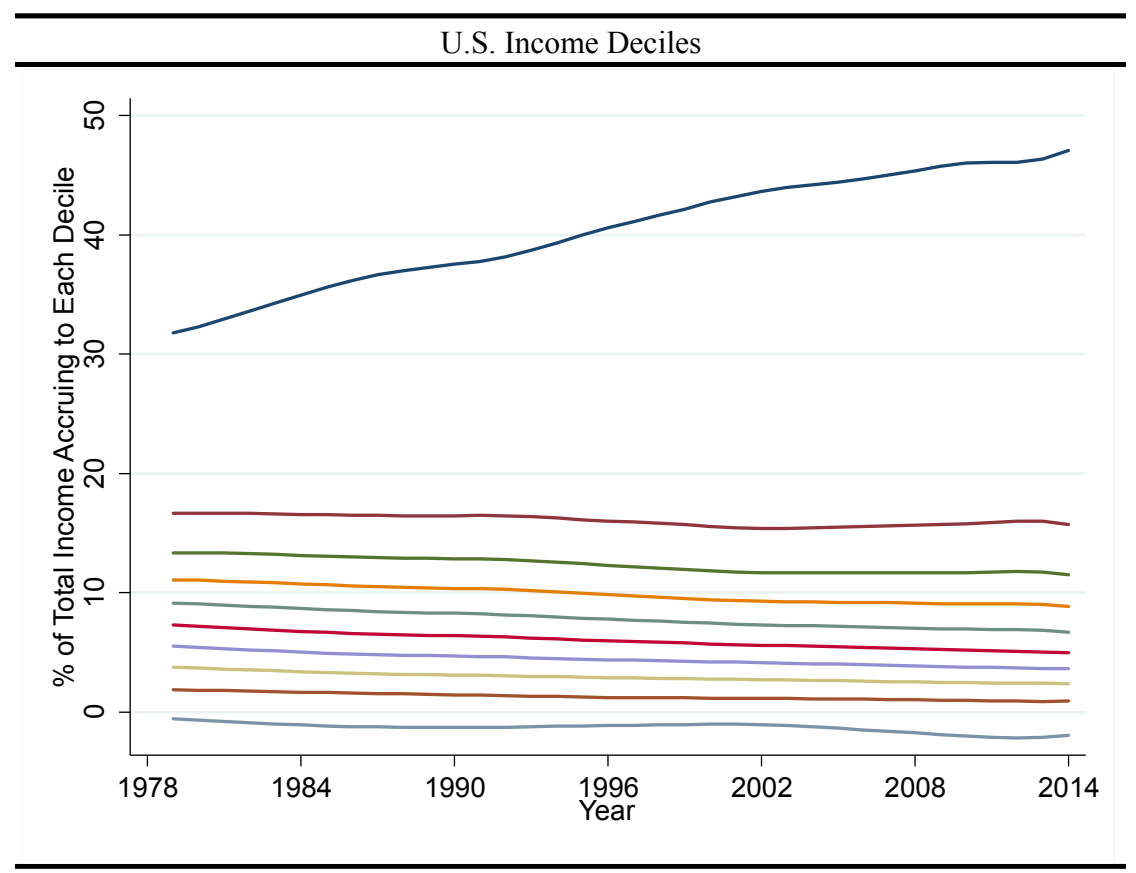

Notes: Kernel-weighted local polynomial smoothed data from World Wealth and Income Database (WID; website: wid.world).

\section{A.2 Top 1\% in Other OECD Countries}

Our analysis examines why top incomes in the U.S. have increased so dramatically, as illustrated in Figure 1. This section provides some evidence on trends in top incomes in other high-income countries.

Employing data from the World Wealth and Income Database (WID: Alvaredo, Chancel, Piketty, Saez, and Zucman), the evolution of the top 1\% fiscal income shares for a variety of OECD countries is shown in Figure A2. The share of income going to the top $1 \%$ has increased in all ten of these countries. ${ }^{66}$

\footnotetext{
${ }^{66}$ We focus on OECD countries that have available data, that are similar to the U.S., or that have been examined for comparison purposes in the literature (Piketty and Saez 2006; Alvaredo et al. 2013).
} 
While the share of income going to top earners has evolved in different ways across these countries, a clear upward trend is evident in Figure A2. In particular, the share of income going to the top earners ranged from $4-10 \%$ early in the sample but by the end of the sample it was in the $8-14 \%$ range. The growth in top incomes is not a phenomenon specific to the U.S. and while there are institutional differences across countries, we see little reason to believe that the forces that affect the relationship between globalization and executive compensation identified in this paper do not apply to other countries as well.

\section{FIGURE A2}

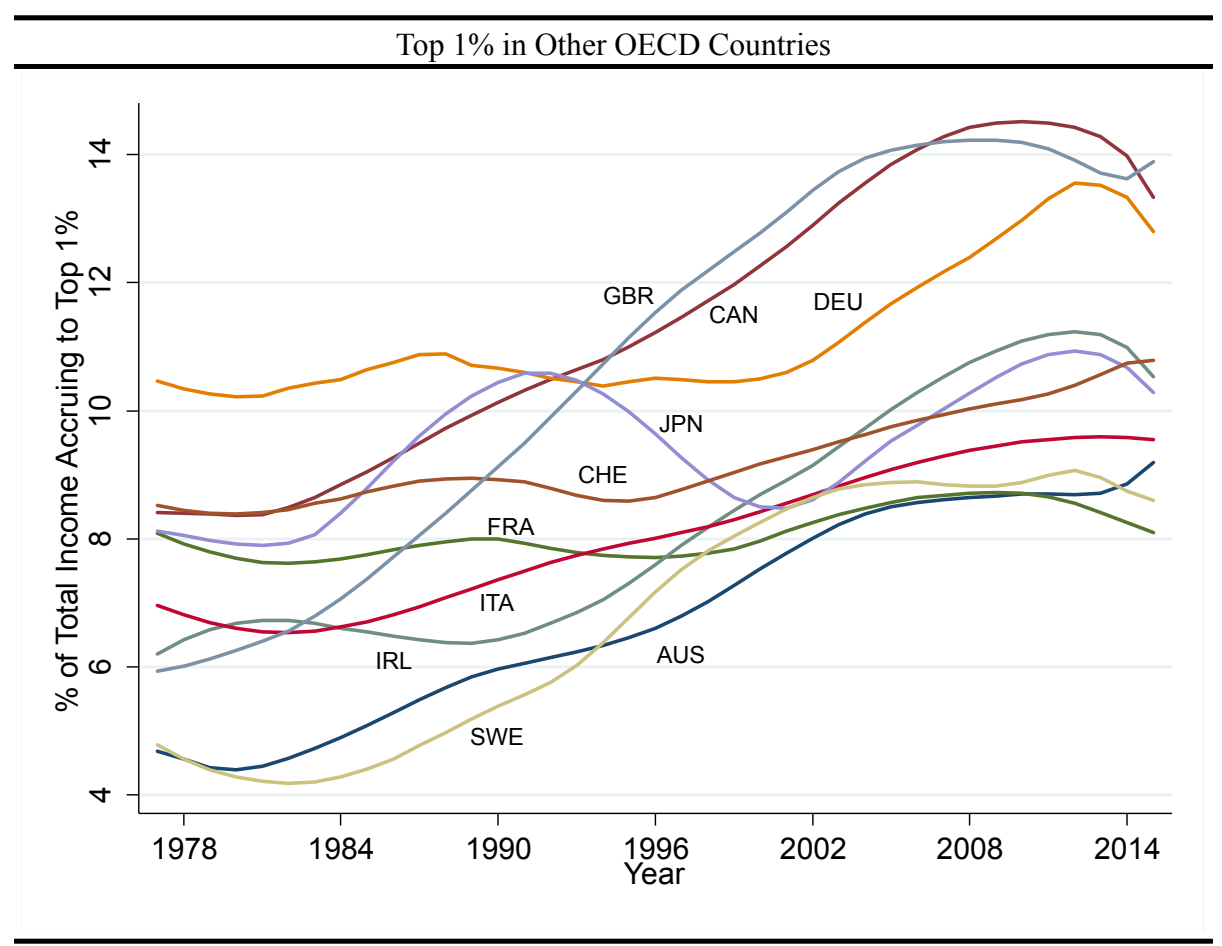

Notes: Kernel-weighted local polynomial smoothed data from World Wealth and Income Database (WID; website: wid.world).

\section{A.3 Time-Series Variation}

Figure A3 examines the relationship of interest between executive composition and globalization using our data. Clearly, both executive compensation and exports have increased substantially over our sample period, 1993-2013. Reassuringly, these results are very similar to the trends seen in Figure 2, which provides additional external validity for our analysis. 


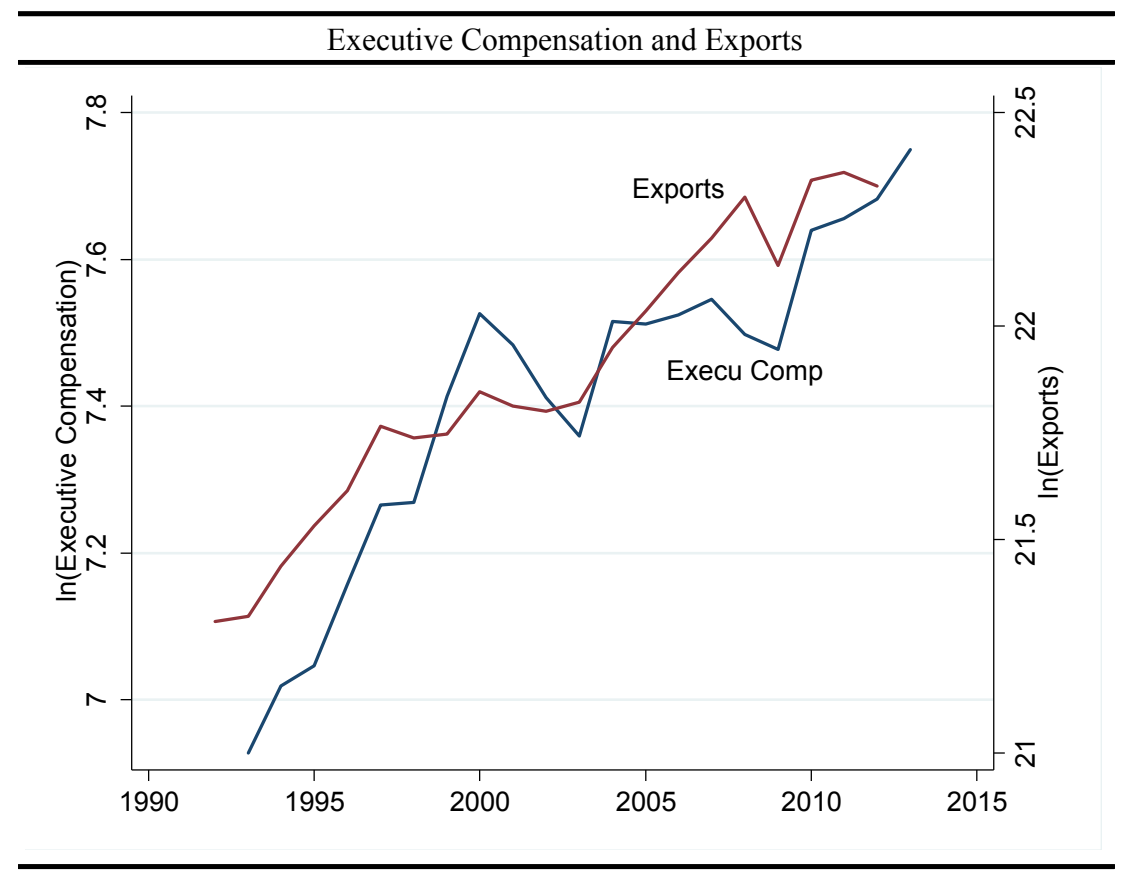

Notes: Average executive compensation (TDC1) and average exports over time. Compensation data for top 5 executives is obtained from the Compustat ExecuComp data set. U.S. industry-level export data for firms in the ExecuComp data set are obtained from the U.S. Census Bureau via Schott's International Economics Resource Page (Schott 2008).

\section{A.4 Measuring Firm Size}

This section demonstrates that our findings are not sensitive to alternate measures of firm size. As in Edmans, Gabaix, and Jenter (2017, Table 2), we examine the relationship between firm size and executive compensation using an OLS specification that includes executive characteristics and year fixed effects. Instead of industry fixed effects, to be conservative we utilize firm fixed effects. Columns 1-6 of Table A4 show how executive compensation varies with a variety of firm size measures, in particular employment, sales, assets, costs, stock price, and market value. All variables enter with a positive and significant coefficient and the magnitudes are similar (with a narrow range of 0.15 to 0.25 across six measures). Note that the latter two measures have the largest coefficients, which is consistent with the observation that executive compensation and these two size proxies are closely related to the firm's stock price.

Next we examine whether exports matter for executive compensation above and beyond firm size. We begin by including exports without controlling for size (see column 7), finding that a ten percent increase in exports is associated with a $0.8 \%$ increase in executive compensation. In columns 8 to 13 we add one size measure at a time to the specification. Including exports and other firm characteristics in the specification 
causes every one of the size coefficients to fall (compare columns 1 to 8, 2 to 9 , etc.). Furthermore, the inclusion of the size measures often causes the export point estimate to decrease too (compare columns 7 to 8,7 to 9 , etc). These results provide additional confirmation that a portion of globalization's effect on executive pay operates through firm size.

Importantly the magnitude of the export coefficient is remarkably stable after the inclusion of a variety of different proxies for firm size. Specifically, there is no statistical difference between the export coefficients using any of the size measures. The fact that the export coefficient is positive, significant, and similar in magnitude in every specification indicates that our finding that globalization increases executive pay conditional on size is robust. We conclude from Table A4 that all measures of firm size generate similar results. 


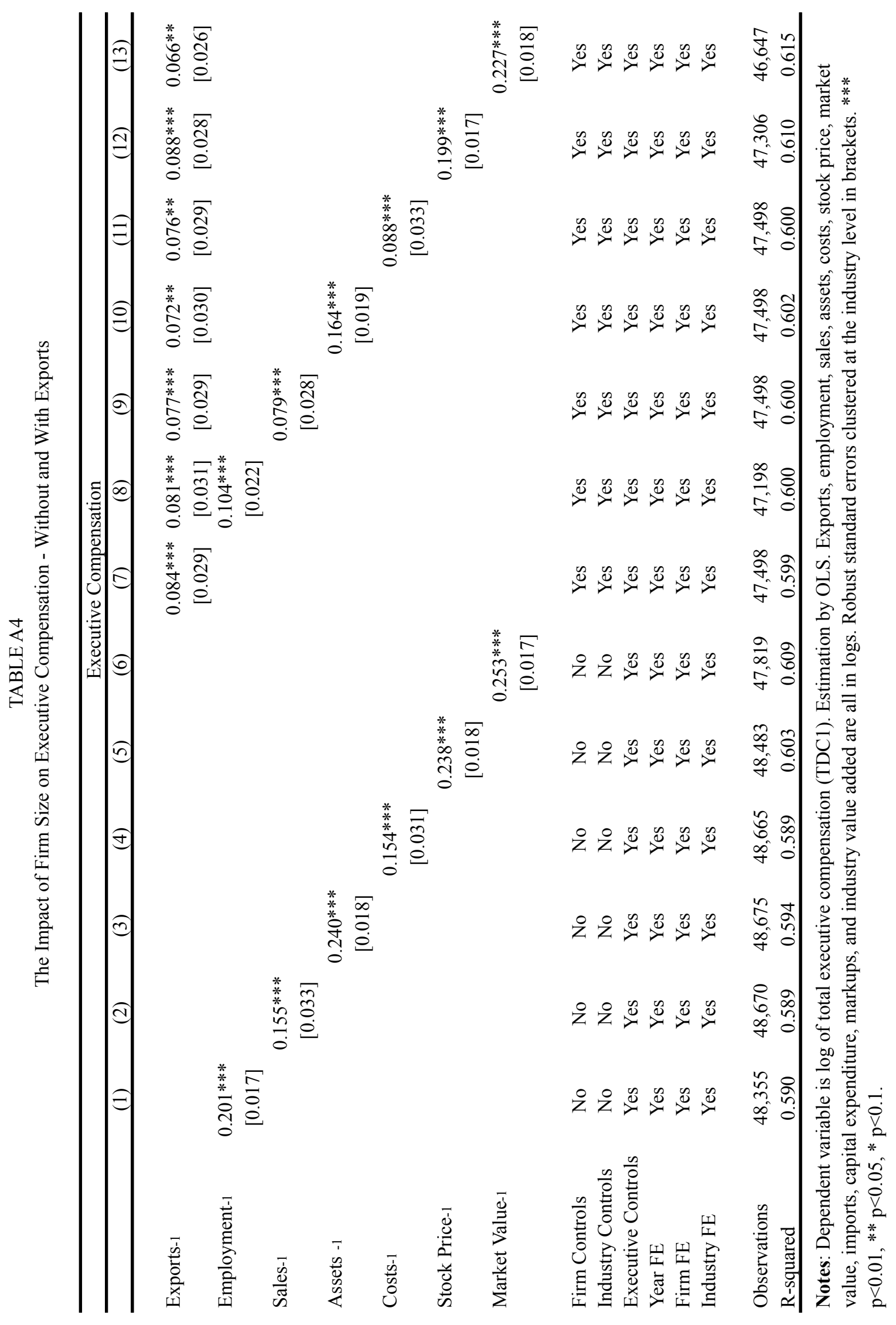




\section{A.5 Top Tax Rates and Sample Selection}

Recent work indicates that top marginal tax rates are an important driver of executive compensation. For example, a lower top marginal tax rates may provide incentives for the executive to bargain more aggressively over pay (Piketty, Saez, and Stantcheva 2014). Using data from the Taxsim database we measure top marginal income tax rates in the state in which the firm is headquartered. While all executives in our data set face the same marginal federal (U.S.) income tax rate, many also pay state income taxes which can vary significantly across states and over time. For instance, the top marginal income tax rate has increased in California from $9.3 \%$ in 1990 to $14.1 \%$ in 2014, has remained at 0\% in Texas, and has decreased from $8.5 \%$ to $5.1 \%$ in New Mexico. We examine whether these changes in top marginal state tax rates can explain part of the growth in top incomes.

As a point of reference, columns 1-2 of Table A5 re-report our main results that include approximately 46,000 observations and do not include top marginal tax rates. Then in columns 3-4, we include our top marginal tax rate variable, which due to limited information on the headquarter state of the firm restricts the sample to 28,000 observations. We find that the top marginal tax rate has a negative impact on total compensation (column 3), which supports the idea that as top marginal tax rates fall executives have more incentive to bargain for higher compensation (Piketty, Saez, and Stantcheva 2014). However, top tax rates have an insignificant impact on bonuses (columns 4). Importantly the inclusion of Top Tax Rate and the associated loss of observations has no qualitative effect on the export coefficients of interest which remains positive and significant.

Columns 5-6 then go one step further by only including firms that span the entire 21 years of the sample. This alleviates concerns that firm entry or exit from the sample may be influencing the results. By restricting the sample in this way, the number of observations falls to approximately 15,000 observations. Despite the loss of sample size, the export coefficients of interest remain positive and significant. If anything, the impact of export shocks on executive bonuses at poor governance firms is now larger (0.384 versus 0.155 in column 2). Again we see that the top marginal tax rate has a negative impact on total compensation but no impact on executive bonuses. Overall Table A5 sheds light on the role of top marginal tax rates and it indicates that our export results are consistent across a variety of different samples. 


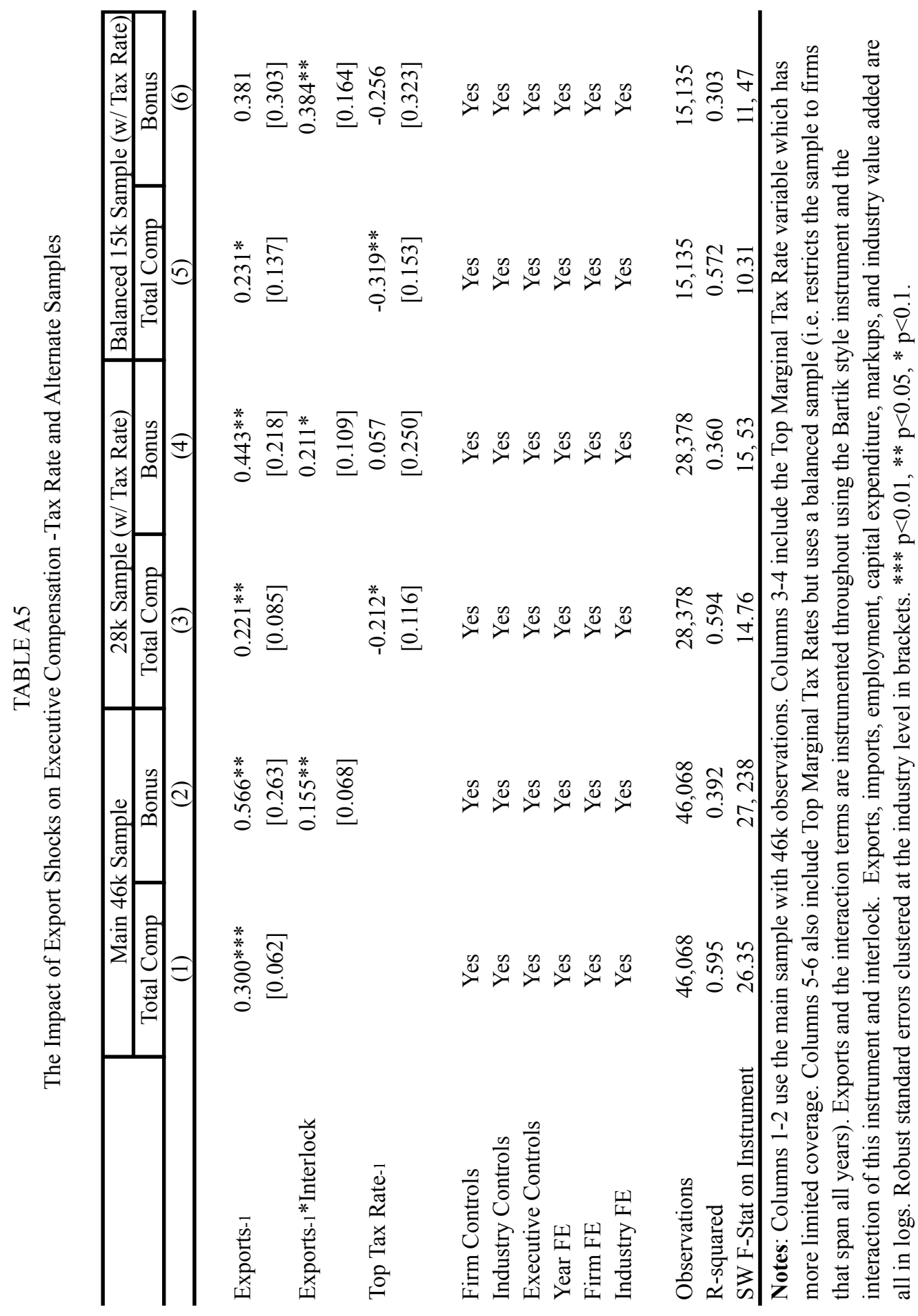

\section{A.6 Poor Governance Details}

Given that export shocks have a positive impact on executive bonuses (see Table 6), our subsequent analysis focused more carefully on this important component of discretionary compensation (see Tables 7-8). This section examines whether export shocks effect other types of compensation at poorly governed firms. Furthermore, we investigate whether there is any evidence that poor governance itself is endogenously 
related to unobserved firm characteristics.

Column 1 of Table A6 shows that export shocks increase total compensation but this effect is not stronger at poorly governed firms. The export point estimates is positive and significant, but the interaction of export shocks with interlock relationships is insignificant. In column 2 we find that export shocks have no impact on less-discretionary salaries, regardless of corporate governance. Column 3 re-reports our previous results showing that export shocks lead to higher executive bonuses and this effect is stronger at poorly governed firms. We find no impact of export shocks on options awarded or on stocks in columns 4 and 5 , regardless of the quality of corporate governance. While we do find in column 6 that export shocks increase other types of compensation, there is no evidence that this relationship is stronger at poorly governed firms. Ultimately, we find that poor corporate governance only influences the relationship between export shocks and discretionary bonuses, which is consistent with rent-capture being important.

We also examine whether poor governance is correlated with unobserved firm characteristics. If these firm characteristics are in turn correlated with executive compensation, this could influence our results. We address this potential issue by constructing measures of poor governance that are less susceptible to endogeneity. Specifically, we calculate firm-level averages of our interlock and board variables over time in order to break the potential link between governance and short-run fluctuations in firm performance. ${ }^{67}$ The results from interacting these alternate poor-governance measures with export shocks are reported in columns 7 and 8. Consistent with the results in column 3, we find that exogenous export shocks disproportionately increase executive bonuses at poor-governance firms. The interaction point estimates are in fact larger in magnitude when defining poor governance using the interlock average (column 7) or the board average (column 8). The important message is that the potential endogeneity of poor governance does not seem to be a main driver of our findings.

\footnotetext{
${ }^{67}$ Firm-level averages over the entire sample are time-invariant and thus subsumed by the firm fixed effects. We split the sample into thirds by taking seven year averages of interlock and board over the periods 1993-1999, 2000-2006, and 2006-2013. The results are similar using different definitions.
} 


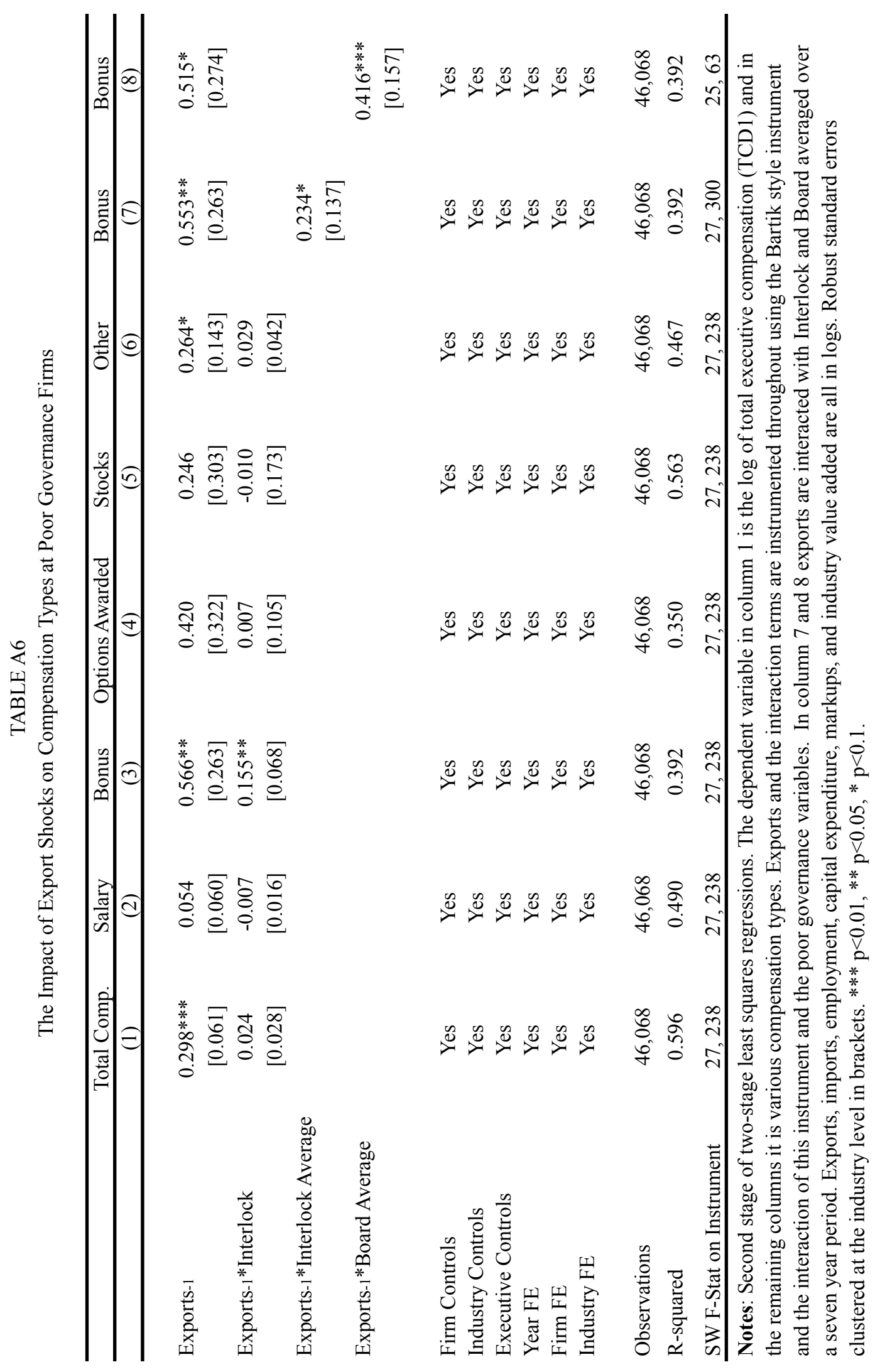




\section{A.7 Import Shocks}

Our analysis has focused on the impact of exports on executive compensation, while adding imports as a regressor throughout. Import competition may adversely affect firm performance which in turn could reduce executive compensation. However, imported inputs may increase firm profits and thus increase executive compensation. While recent studies have found an adverse impact of imports on workers, this may not be the case for top-level executives (Cuñat and Guadalupe 2009). This section extends our analysis by examining the impact of exogenous import shocks on executive compensation.

We construct an analogous Bartik style instrumental variable for imports. Specifically, this import instrument is constructed using presample bilateral import flows and the growth in industry-level imports in other high-income countries. ${ }^{68}$ Column 1 of Table A7 reports our main results that instrument for exports. Column 2 then instruments for imports instead, using a Bartik inspired import IV analogous to equation (2). While the import instrument successfully predicts actual import flows (the SW first stage Fstatistic is large), the second stage coefficient on imports is close to zero, indicating that exogenous import shocks have no effect on executive compensation. Notice that the uninstrumented export coefficient remains positive, significant, and similar in magnitude to the uninstrumented export coefficient from column 4 of Table 2. Column 3 then simultaneously instruments for both exports and imports and finds that both firststages are strong. However, in the second-stage, only the export coefficient is statistically significant and the magnitude of this coefficient increases relative to column 1. Imports have a negative point estimate, but in our analysis it is not significantly different from zero. Overall, we find that exports and export shocks both significantly increase executive compensation, while imports and import shocks have little effect on top incomes.

\footnotetext{
${ }^{68}$ Note that we prefer not to construct import exposure using business segment data, since doing so would cause exports and imports to be highly correlated due to mechanical reasons (i.e. they both would be functions of the same underlying business segment shares). Results are similar if both export and import exposure are measured at the main industry level (see Appendix A.8).
} 
TABLE A7

The Impact of Export and Import Shocks on Executive Compensation

\begin{tabular}{lccc}
\hline & Export IV & Import IV & Export and Import IV \\
\hline & $(1)$ & $(2)$ & $(3)$ \\
\hline Exports-1 & & & \\
& $0.300^{* * *}$ & $0.067^{*}$ & $0.332^{* * *}$ \\
Imports-1 & {$[0.062]$} & {$[0.034]$} & {$[0.082]$} \\
& 0.000 & 0.049 & -0.040 \\
& {$[0.010]$} & {$[0.039]$} & {$[0.047]$} \\
Firm Controls & & & \\
Industry Controls & Yes & Yes & Yes \\
Executive Controls & Yes & Yes & Yes \\
Year FE & Yes & Yes & Yes \\
Firm FE & Yes & Yes & Yes \\
Industry FE & Yes & Yes & Yes \\
& Yes & Yes & \\
Observations & & & 46,058 \\
R-squared & 46,068 & 46,058 & 0.594 \\
SW F-Stat on Instrument & 0.595 & 0.599 & 44,19 \\
\hline
\end{tabular}

Notes: Second stage of two-stage least squares regressions. Column 1 reports the baseline export IV results. Instead, column 2 instruments for imports using an analogous Bartik style import instrument. Finally, column 3 instruments for both exports and imports simultaneously. Exports, imports, employment, capital expenditure, markups, and industry value added are all in logs. Robust standard errors clustered at the industry level in brackets. ${ }^{* * *} \mathrm{p}<0.01,{ }^{* *} \mathrm{p}<0.05, * \mathrm{p}<0.1$.

\section{A.8 Additional Sensitivity Findings}

Table A8 presents a number of additional sensitivity checks. Column 1 re-reports our earlier results from the main text for comparison purposes. Columns 2-4 then explore alternate ways of defining exports and export shocks. Specifically, column 2 uses product level exports in the firm's main industry (which is defined by ExecuComp) rather than using firm-specific exports which is constructed as the weighted share of exports across the firm's top three business segments. The export coefficient is now estimated to be 0.22 (versus 0.30 from column 1). It is possible that the additional information on the business segments of the firm allow us to more clearly estimate the pay responses to exogenous export shocks. Despite this alternate method of constructing exports, we see that the results are similar.

Returning to our preferred firm-specific export measure, column 3 explores an alternate method of linking the firm to industry-level export shocks. Specifically, in the baseline analysis each firm is exposed to industry export shocks in its time-invariant main industry as defined by ExecuComp. In contrast, column 3 uses a time-varying measure of the firm's main NAICS industry from Compustat. The benefit of using this time-varying industry shock is that it accounts for the possibility that a firm's primary industry 
may change over the sample. The downside is that potentially small changes in a firm's composition of production, which shift it from one NAICS primary industry to another, could translate into large changes in measured global exposure. This may generate noisy swings in the data, when in fact the firm's switch from one NAICS industry to another may represent a rather small readjustment of the firm's activities. ${ }^{69}$ Column 3 uses this time-varying measure of the firm's export shock, it includes time-varying industry fixed effects, and we see that the impact of export shocks on compensation remains largely unchanged.

Column 4 also uses our firm-specific export variable, but defines the firm's time invariant main industry using business segment sales rather than using the ExecuComp definition. As we see, the coefficient on exports remains similar. Overall, columns 2-4 indicate that the results are not sensitive to how export exposure is defined.

Our preferred measure of total compensation (TDC1) includes options awarded to an executive in a given year. Column 5 utilizes an alternate measure of total compensation (TDC2), which includes stock options exercised rather than awarded. Comparing the export point estimate in columns 1 and 5, we find that export shocks have a more positive impact on TDC2, which is consistent with the idea that executives strategically exercise their options after a positive global shock.

Rather than relying on board-based measures of poor governance, column 6 uses an entirely different measure based directly on the co-movement of the firm's stock price and executive compensation. Specifically, we define the binary variable rent to equal one if the firm's stock price fell but average executive compensation at the firm rose in a given year. In a sense, this is an ex-post measure of poor governance. The results indicate that defining poor governance in this way also generates a significant positive coefficient and does not alter the export coefficient of interest. Thus, we see that our results are robust to using a measure of poor governance that is not based on the structure and composition of the board of directors at the firm.

Column 7 employs an alternate measure of technology investment. Rather than including capital expenditures which are used elsewhere in our analysis, we now include R\&D expenditures. Unfortunately the data coverage of the $\mathrm{R} \& \mathrm{D}$ variable is limited and thus we lose almost a quarter of the observations. Nonetheless, R\&D expenditures have a significant positive impact on executive compensation. Importantly the inclusion of R\&D and the subsequent loss of sample size does not alter the export coefficient of interest.

We also examine whether globalization increases executive pay by increasing the complexity of an executives job. We measure complexity using the number of destination markets that the firm's main

\footnotetext{
${ }^{69}$ See Keller and Yeaple (2009) on the consequences of this in the context of FDI spillovers.
} 
industry exports to, with the idea that a manager's job is more complex if they serve more foreign markets. In column 8, we find that complexity has little bearing on executive pay, while the impact of export shocks remains an important predictor of compensation. 


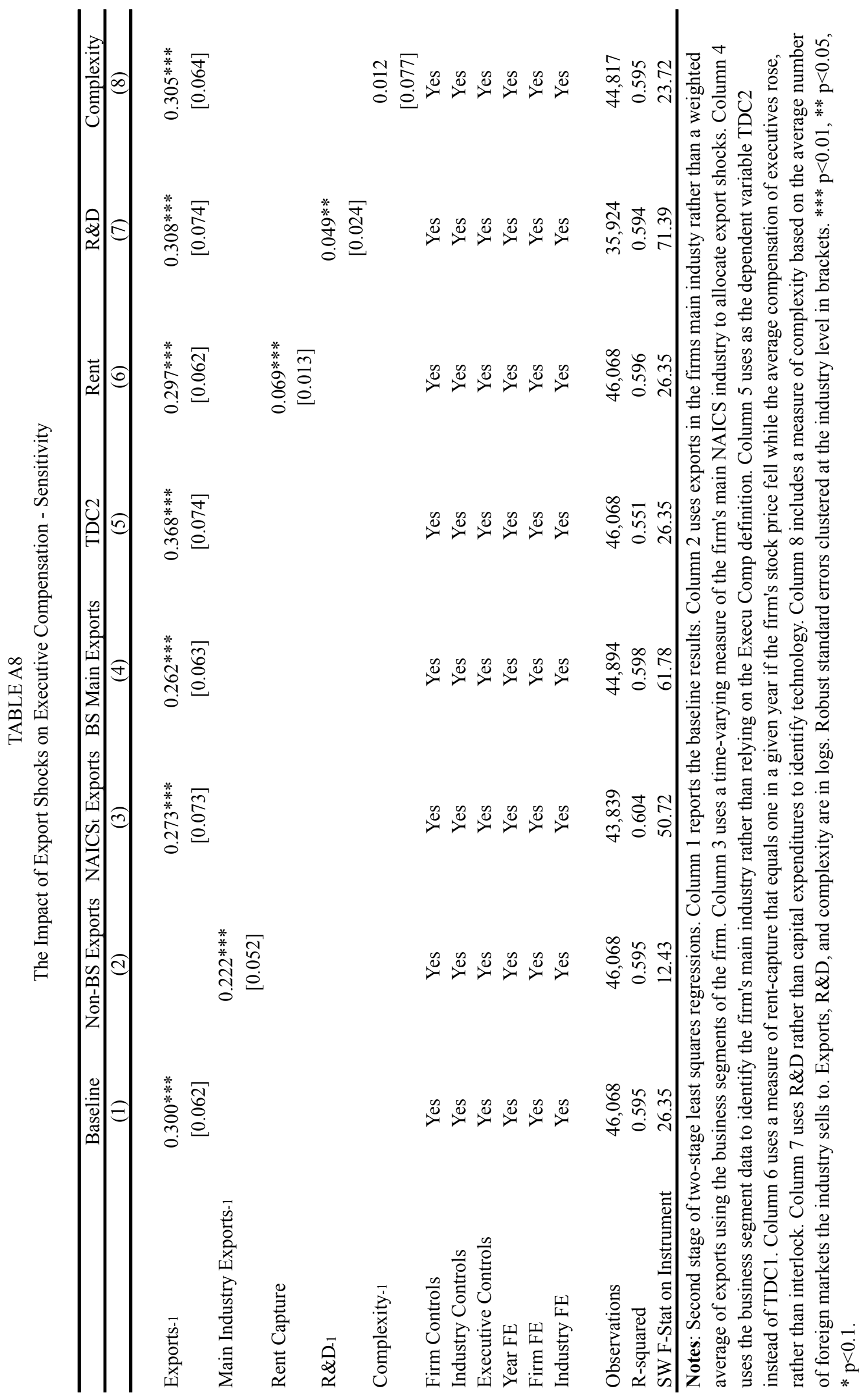




\section{A.9 Additional Instrumental Variable Details}

This section provides additional details on the construction of the world import demand and exchange rate instrumental variables. First, the World Import Demand (WID) instrument identifies variation in U.S. exports using information on foreign import demand conditions. This instrument is constructed by allowing presample bilateral U.S. exports to grow at the exogenous rate at which non-US imports into a foreign country increased within an industry. Formally, the WID instrument is constructed in the following way:

$$
W I D \_e x p \_i v_{n t}=\sum_{c}\left(\exp _{n c 1991} *\left(1+g_{c n t}^{W I D}\right)\right)
$$

Like the Bartik approach, we use presample 1991 U.S. bilateral export flows in industry $n$ and to foreign country $c$ (see equation 2). The difference is that now we multiply presample export flows by the growth rate of world imports of good $n$ into country $c$ between 1991 and year $t$. To ensure that we are identifying an exogenous source of variation in world imports, we exclude any imports coming from the U.S. Unlike the Bartik instrument, this WID instrument uses an exogenous growth rate $g$ that varies by foreign country $c^{70}$ The final step is to sum across foreign trade partners to generate an industry-year specific World Import Demand instrument.

Second, our exchange rate instrument identifies variation in U.S. exports arising from the fact that some industries will be more exposed to exchange rate fluctuations in a particular foreign country than other industries. Specifically, the instrument is constructed in the following way:

$$
E R_{-} e x p_{-} i v_{n t}=\sum_{c}\left(\exp _{n c 1991} *\left(1+g_{c t}^{e x}\right)\right) .
$$

We use presample 1991 U.S. bilateral export flows in industry $n$ and to foreign country $c$, as before. The difference is that now we multiply presample export flows by the percent change in the exchange rate in country $c$ between 1991 and year $t$. The exchange rate is defined as the foreign country's currency per U.S. dollar. Like the WID instrument the exogenous growth rate $g$ varies by foreign country $c$ but unlike the

\footnotetext{
${ }^{70}$ Similar to the Bartik IV, we can construct the instrument for years in which there are no bilateral trade flows in an industry (assuming of course that bilateral exports exist in the presample year). However, world import demand growth rates $(g)$ do need to be restricted to country-industry pairs that span all the years in the sample to ensure that the instrument is based on a balanced sample. The firm's main industry $n$ is defined using business segment data at the 4-digit NAICS level.
} 
two other instruments it does not vary by industry $n .^{71}$ Then we sum across trade partners to generate an industry-specific export instrument that relies on variation in exchange rates that affect some industries more than others based on presample export flows.

\footnotetext{
${ }^{71}$ We focus on the top 100 U.S. trading partner countries and can construct the instrument for years in which there are no bilateral trade flows in an industry. Thus, this instrument is balanced and does not capture extensive margin adjustments into or out of foreign destination markets which could be endogenous. The firm's main industry $n$ is defined using business segment data.
} 